\title{
Non-destructive testing and Finite Element Method integrated procedure for heritage diagnosis: The Seville Cathedral case study
}

\author{
Eduardo Diz-Mellado a , Emilio J. Mascort-Albea ${ }^{\mathrm{b}}$, Rocío Romero-Hernández ${ }^{\mathrm{b}}$,

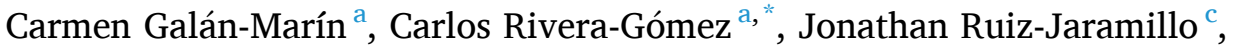 \\ Antonio Jaramillo-Morilla ${ }^{\mathrm{b}}$ \\ ${ }^{a}$ Departamento de Construcciones Arquitectónicas 1, Escuela Técnica Superior de Arquitectura, Universidad de Sevilla, Avda. Reina Mercedes, 2, 41012, Seville, Spain \\ ${ }^{\mathrm{b}}$ Departamento de Estructuras de Edificación e Ingeniería Del Terreno, Escuela Técnica Superior de Arquitectura, Universidad de Sevilla, Avda. Reina Mercedes, 2, \\ 41012, Seville, Spain \\ c Área de Estructuras y Construcciones Arquitectónicas, Escuela Técnica Superior de Arquitectura, Universidad de Málaga, Málaga, Spain
}

\section{A R T I C L E I N F O}

\section{Keywords:}

Building heritage

Non-destructive testing (NDT)

Infrared thermography (IRT)

Laser levelling (LL)

Accelerometer measures (AM)

Ground-penetrating radar (GPR)

Finite element method (FEM)

\begin{abstract}
A B S T R A C T
One of the major problems faced by historic cities today involves the conservation of heritage buildings. Damage suffered by these buildings can be irreversible and fast-acting, leading to their disappearance over a short period. The study and analysis of the origin of the damage suffered by these buildings have proved themselves to be key to their conservation. Non-destructive testing (NDT) can detect problems indiscernible to the naked eye, thereby preventing potential losses. In this paper, a non-invasive method for the diagnosis of building structures integrated with the Finite Element Method (FEM) was applied to the Tabernacle Chapel; a building included in the northwest wing of the Cathedral of Seville complex. Despite the many interventions carried out to date, the issue of the chapel's deterioration has yet to be entirely solved. This research describes the results of a detailed constructive and structural diagnosis methodology for heritage buildings. The data provided from NDT methods, such as Digital Image Processing (DIP), Infrared Thermography (IRT), Laser Levelling (LL), Ambient Vibration Testing (AVT), and Ground-Penetrating Radar (GPR), has been verified and integrated as boundary conditions in a 3D Finite Element Method (FEM) in order to establish the critical points of the structure, including the failure mechanisms. The results led to the conclusion that the main causes of deterioration involved the settling of the grandstand built in the northwest sector of the building and the effects of the thrusts of the dome on the lateral façades. An integrated implementation methodology of NDT and FEM has enabled accurate knowledge to be ascertained of the principal damage affecting this heritage building.
\end{abstract}

\section{Introduction}

Architectural heritage is exposed to a myriad of hazards that affect its state of conservation. Countless generations over the centuries have felt themselves responsible for the preservation of their inherited legacy, and have defined valid paradigms and operational procedures [1]. Preventive conservation is of major importance today, since it is considered one of the main disciplines in the preservation of architectural heritage [2]. Conceived from a transversal and inter-disciplinary perspective, this concept strives for the development of a set of systematised and periodical activities for the promotion of the correct visibility, understanding, and maintenance of the analysed heritage building [3]. All of this materialises into a set of preventive actions, based on monitoring and follow-up maintenance tasks, aimed at minimising future deterioration $[4,5]$.

By bearing the impact on the materials of the building in mind, the methods applied in the analysis and diagnosis of buildings structures may be classified into three types: destructive, semi-destructive, and non-destructive [6]. The most useful Non-Destructive Testing (NDT) methods, based on the information they provide and their performance, are Digital Image Processing (DIP) [7], Photogrammetry (P) and Stereo photogrammetry (SP) $[8,9]$, Laser levelling (LL), Ambient Vibration Testing (AVT) [10], Infrared Thermography (IRT) [11], and underground mapping analysis by Ground-Penetrating Radar (GPR) [12]. The validation of the techniques and the tests run in the laboratory through computer programs have enabled a huge leap in terms of conservation of

\footnotetext{
* Corresponding author.

E-mail address: crivera@us.es (C. Rivera-Gómez).
} 


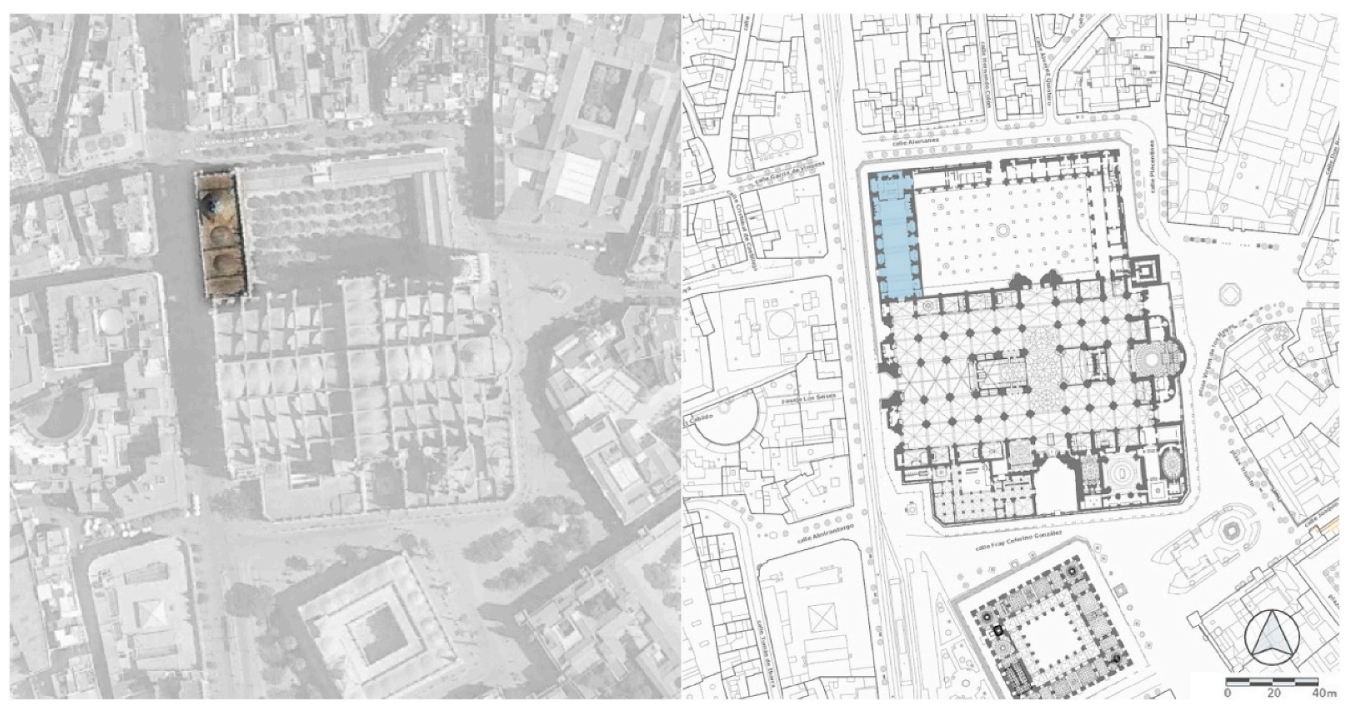

Fig. 1. Location of the tabernacle chapel in seville cathedral.

architectural heritage in recent decades [13]. These NDTs are, to a certain extent, controversial: they are considered very favourable techniques by many researchers, but unreliable by others [14], and have successfully been applied in ancient religious and heritage buildings with proven results [15]. Previous research shows how a detailed study of cultural heritage structures generally requires the application of various detection techniques, along with historical and technical knowledge [16]. The multidisciplinary synergy of NDT in recent decades has made it possible to identify damage that architects and engineers were previously unable to analyse [17]. The use of NDT to study the damage of the church of San Juan Bautista in Spain led to the detection of the humidity that was the underlying cause of the damage [18]. Chastre et al. [19] state that it is impossible to carry out destructive tests in most historical buildings due to the damage this would imply to the heritage asset. For this reason, it is preferable to choose NDT or other similar methodologies that enable the physical and mechanical characterisation of the structures and materials of heritage buildings. Consequently, the combined application of these techniques provides significant information on the geometry, materials, constructive stages and structural descriptions of historical buildings [20,21].

Previous research, such as the methodology developed by Lourenço et al. [22] in the Monastery of San Jeronimo in Lisbon, combines non-destructive inspection techniques with structural analysis tools. The combination of these two techniques is a major factor in the improvement of the conservation of cultural heritage. Other research, such as that conducted on the dome of the Cathedral of Pisa, carries out a methodological process based on laser scanning and photogrammetric tools to achieve concise and detailed structural models [23].

The strategies for the conservation of architectural heritage require the use of tools that lead to a deeper understanding of the complex behaviour of these structures. As a result, the correct diagnosis of their state of conservation can be achieved, thereby preventing the appearance of damage and providing new solutions [24]. In addition, previous research shows how the use of current tools, such as the Geographical Information System (GIS), has allowed georeferenced data previously collected in heritage buildings to facilitate a study of the dynamic process of damage in heritage buildings [25]. Previously, NDTs have been integrated with other software, such as Building Energy Modelling (BEM), to better characterise the model, and for a greater understanding of the thermodynamics of the building envelope. This integration, however, can also be carried out for the study of damage in heritage architecture [14]. In this respect, computer analysis using the Finite Element Method (FEM) [26,27] enables some of the results obtained with NDT to be verified, and is therefore helpful in the effective identification and structural diagnosis of typologically differentiated heritage case studies [28]. The information provided by the NDTs is employed to calibrate the models when both tools are combined [27, 29].

This paper focuses on the application of the aforementioned strategies on the study of a leading example of Spanish architectural heritage: the Tabernacle Chapel of Seville Cathedral. The case study has been chosen not only due to its extensive damage but also for being an example where the application of NDT has enabled full understanding of the origin of the existing pathologies. The data gathered has allowed for the evaluation of the current state of the building, and has increased the possibility of finding the origin of the existing damage.

This research aims to provide a comprehensive approach to studying and understanding the structural and constructive deterioration of heritage buildings through the application of NDT and FEM in a methodological feedback process. Once all the procedures have been applied and the data gathered, the evaluation of the identified pathologies can be performed, and a methodology is provided that can be applied in future interventions on historic buildings. The NDTs employed can complement each other towards improving the volume of data collected in order to be able to compare and have a hypothesis of the damage [17]. Hitherto, there has been very little research that uses both techniques together, except for simply using non-integrated NDT and FEM to value the damage in certain heritage buildings [30]. The outcome of this paper illustrates the potential and validity of the combined and integrated use of NDT and FEM for a better understanding and diagnosis of historical buildings of great complexity and heritage value.

\section{Case study}

The Cathedral of Santa Maria in Seville is a cultural heritage site built on top of the remains of Seville's Old Great Mosque, and is considered the largest Gothic cathedral in the world. In 1987, its historical-artistic relevance was officially recognised through its incorporation into the UNESCO World Heritage List [31,32]. The current configuration of Seville Cathedral is the consequence of continuous extensions and modifications incurred throughout its history, which in many cases are the result of interventions triggered by natural phenomena, such as earthquakes, floods and thunderstorms $[33,34]$ as well as anthropogenic actions, such as demolitions and pollution [35].

The Tabernacle Chapel was designed during the 17th century as an independent building, in the Baroque period [36,37]. The case study extends over a total area of $1121.12 \mathrm{~m}^{2}$, with a total length of $57.20 \mathrm{~m}$ (m), a width of $19.60 \mathrm{~m}$, and a ceiling height of $16.00 \mathrm{~m}$. The roof of the 


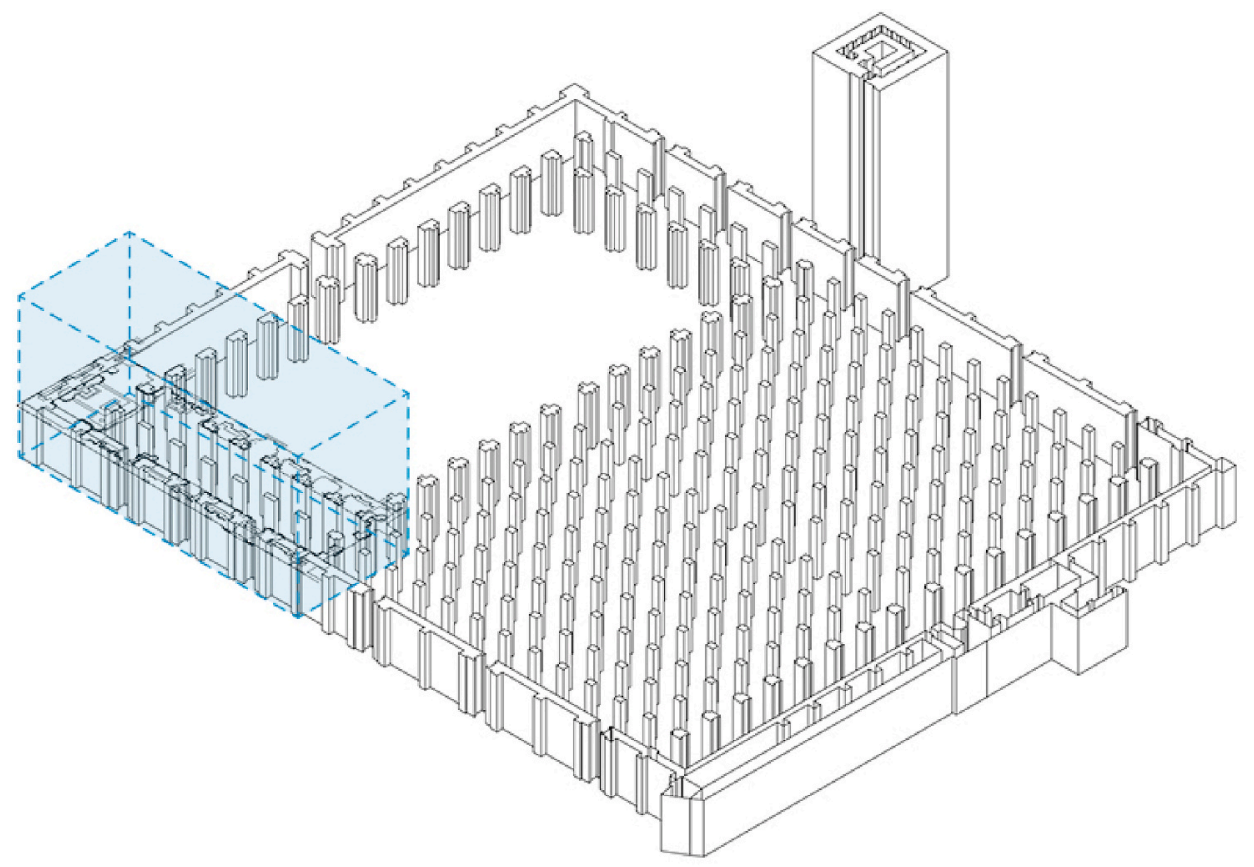

Fig. 2. Relationship between the Tabernacle Chapel and the pre-existing structures of Seville’s Old Great Mosque based on Jiménez-Martín's hypothesis. Perspective drawing of the old mosque and volume of the case study.

Table 1

Chronological process of the Tabernacle Chapel's construction phases.

\begin{tabular}{|c|c|c|c|}
\hline $\begin{array}{l}1617- \\
1660\end{array}$ & $\begin{array}{l}\text { Phase 1: Construction of } \\
\text { the building }\end{array}$ & $1660-2020$ & Phase 2: Interventions \\
\hline 1617 & $\begin{array}{l}\text { Beginning of the } \\
\text { construction work }\end{array}$ & 1692 & Arch reinforcement \\
\hline 1630 & Completion of foundations & 1730 & $\begin{array}{l}\text { Stained-glass substitution } \\
\text { and roof repair }\end{array}$ \\
\hline 1640 & $\begin{array}{l}\text { Construction of all the } \\
\text { stone masonry walls up to } \\
\text { the first cornice }\end{array}$ & 1755 & $\begin{array}{l}\text { Bracing reinforcements of } \\
\text { the building subsequent to } \\
\text { the Lisbon Earthquake }\end{array}$ \\
\hline 1649 & Construction shutdown & 1776 & $\begin{array}{l}\text { Replacement of ashlars and } \\
\text { lightning of the roof and } \\
\text { walls }\end{array}$ \\
\hline 1656 & $\begin{array}{l}\text { The dome over the } \\
\text { transept and vaults are } \\
\text { built. Underground crypt } \\
\text { opening }\end{array}$ & 1963 & $\begin{array}{l}\text { Overall consolidation work } \\
\text { structural reinforcement } \\
\text { and lantern addition }\end{array}$ \\
\hline 1660 & $\begin{array}{l}\text { Completion of } \\
\text { construction }\end{array}$ & 2020 & $\begin{array}{l}\text { Reinforcement of the } \\
\text { foundations }\end{array}$ \\
\hline
\end{tabular}

church is almost flat built through sail vaults and is completed by a dome with a lantern over the transept, which reaches $27.00 \mathrm{~m}$ at its highest point. Located on the north-western side of the Cathedral (Fig. 1), the case study is perceived as a rectangular prism which has two corner façades adjoining Constitucion Avenue (western side) and Alemanes Street (northern façade), with independent entrances from the public space.

\subsection{Chronological phases}

The construction process faced several setbacks, mainly due to its placement over the foundations of the ancient mosque, the weakness of the soil, and the weight of the new building. Regarding pre-existing conditions, the most widely accepted historiographical hypothesis concerning the construction of the building on top of the foundations of Seville's Old Great Mosque is shown in Fig. 2. On redrawing the plan of the ancient mosque, the overlap of the plan of the Tabernacle Chapel over the old mosque is revealed [38,39].

A chronological study of the Tabernacle Chapel reveals the different stages of the construction of the building (Phase 1: 1617-1660) and the specific interventions that have been carried out over its more than three hundred years of existence (Phase 2: 1660-2020). All further interventions have resulted from the continuous presence of constructive and structural issues during the life of the building (Table 1) [40].

\subsection{Construction materials}

According to the chronological analysis, the architectural skeleton of the building is almost totally composed of stone masonry. Over the course of several centuries, stone blocks with similar mechanical properties were extracted from these locations to build remarkable buildings, such as the Andalusian cathedrals [41].

The working hypothesis of this research estimates that the foundation elements of the Tabernacle Chapel are made of a very low-resistance type of calcarenite stone [42]. Additionally, the load-bearing walls, pilasters, arches, vaults, and domes of the building are made of clastic

Table 2

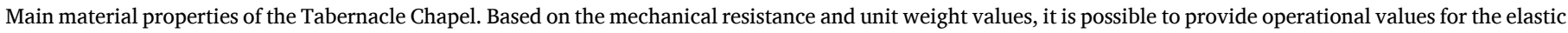
characteristics of the materials.

\begin{tabular}{|c|c|c|c|c|c|c|}
\hline & \multicolumn{2}{|l|}{ Elastic Module } & \multicolumn{2}{|c|}{ Poisson Coefficient } & \multirow[t]{2}{*}{ Unit Weight $\left(\mathrm{kN} / \mathrm{m}^{3}\right)$} & \multirow[t]{2}{*}{ Compressive strength (MPa) } \\
\hline & Dynamic $E_{\text {dyn }}(\mathrm{GPa})$ & Elastic $E_{\text {st }}(\mathrm{GPa})$ & Dynamic $V_{\text {dyn }}$ & Elastic $V_{\text {st }}$ & & \\
\hline Stone masonry & 2.46 & 1.81 & 0.25 & 0.38 & 23.50 & 2.70 \\
\hline Stone foundation & 2.34 & 1.67 & 0.31 & 0.47 & 21.10 & 1.20 \\
\hline Concrete reinforcements & 28.00 & 28.00 & 0.20 & 0.20 & 25.00 & 28.00 \\
\hline
\end{tabular}


Table 3

Geometric and structural parameters. According to the following nomenclature: Rat-L/W (Building Length/Width Ratio); Rat-H/W (Building Height/Width Ratio); St-D (Structural Element Density); W-Th (Wall Thickness); Op-\% (Opening in Wall Percentage); Vt-Sl (Wall Vertical Slenderness. Height/Thickness Ratio); Fr-L (Wall Free Length. Length/Thickness Ratio). The different percentages have been calculated according to the respective elevation and plan surfaces of the elements analysed.

\begin{tabular}{clllllll}
\hline & Rat-L/ & Rat- & St-D & W-Th & Op- $\%$ & $\begin{array}{l}\text { Vt- } \\
\text { Sl }\end{array}$ & $\begin{array}{l}\text { Fr- } \\
\text { L }\end{array}$ \\
\hline $\begin{array}{c}\text { Tabernacle } \\
\text { Chapel }\end{array}$ & 2.00 & 2.20 & $22.4 \%$ & $1.00 \mathrm{~m}$ & 10 & 8.7 & 3.3 \\
$\begin{array}{c}\text { Reference } \\
\text { Values }\end{array}$ & $\leq 2$ & $\leq 4$ & $\approx 20 \%$ & $\begin{array}{l}>0.35 \\
\mathrm{~m}\end{array}$ & $<40 \%$ & $\leq 9$ & $\leq 7$ \\
\hline
\end{tabular}

sedimentary rocks: mainly calcarenites and sandstones [43-45]. According to the consulted technical reports, these tests showed that the building material can be identified as a calcareous stone, which has an average unconfined compressive strength of $2.70 \mathrm{MPa}$ and two subtypes of variations: simple calcareous sandstone and silt calcareous sandstone [46]. As a summary, Table 2 provides a list of the values of the main building materials that have been determined for this research.

\subsection{Structural system approach}

Structurally, the Tabernacle Chapel works as a box of $57.20 \mathrm{~m} \times$ $19.60 \mathrm{~m} \times 24.50 \mathrm{~m}$, emphasised along the longitudinal axis and supported by pilasters that transfer the weight of the sail vaults to the main walls of the building. A remarkable dome of $10.00 \mathrm{~m}$ in diameter and several sail vaults of various sizes and proportions configure the flat roof of the building. Table 3 provides the geometrical parameters for the evaluation of the structure to anticipate certain mechanical behaviours in a theoretical way, as a preliminary overview to further calculations and models. In this case, the coefficients are based on experimental and numerical studies that provide interesting reference values [47].

Additionally, it is considered that the load-bearing walls are supported by continuous footings of $1.50 \mathrm{~m}$ wide, which transmit their load to a layer of anthropic fill soil at an approximate depth of $4.50 \mathrm{~m}$.

\subsection{Soil properties}

The Tabernacle Chapel is located on an area with a stratigraphic configuration that is highly representative of subterranean Seville. Generally, it consists of a layer of anthropic fill that characterises the historical city, supported by alluvial soils with deposits of clay, sand, and gravel whose layers are of varying thicknesses, which are located on a bed of blue marlstones. Additionally, the phreatic level (PL) often appears in superficial levels as a consequence of the existence of numerous underground courses and the proximity to the Guadalquivir River [48]. From these factors, the geotechnical hypothesis indicated in Fig. 3 and Table 4 has been completed with geotechnical studies carried out in the surroundings of the case study [49].

\section{Methodology}

Given the main characteristics of the building, the need for a complete and rigorous diagnosis has been established for the evaluation of the origin of the damage suffered by the Chapel [50]. The number and complexity of the circumstances that must be considered in the pathological diagnosis of a structure increase considerably in the case of historical buildings, where there is a general lack of complete information regarding the original construction. It is therefore necessary to propose phases and tasks that enable the various dimensions and factors of the issue, which usually overlap, to be understood and studied separately, in order to be able to approach this issue with a comprehensive perspective.

Consequently, a methodological approach is proposed that combines the use of NDT with the complementary development of FEM through a non-invasive characterisation protocol that integrates the two techniques. This procedure enables work to be organised in the following 4 thematic areas (Fig. 4). Documentary studies: general information on the building through an estimate of basic values from the study of documentary and bibliographic sources; NDT basic definition: confirmation of the basic properties of the building and their context; NDT

Table 4

Geotechnical ground data of the shallow layers.

\begin{tabular}{|c|c|c|}
\hline \multicolumn{3}{|l|}{ Fill } \\
\hline $\begin{array}{l}\text { Depth: } 0.00 \\
\text { m-4.50 m } \\
\text { Phreatic level: } \\
5.00 \mathrm{~m}\end{array}$ & $\begin{array}{l}\text { Unit weight }(\gamma)=17 \\
\mathrm{kN} / \mathrm{m}^{3}\end{array}$ & $\begin{array}{l}\text { Friction angle }(\Phi)=25^{\circ} \\
\text { Unconfined compressive } \\
\text { strength }\left(\mathrm{q}_{\mathrm{u}}\right)=30 \mathrm{kN} / \mathrm{m}^{2}\end{array}$ \\
\hline \multicolumn{3}{|l|}{ Clay } \\
\hline $\begin{array}{l}\text { Depth: } 4.50 \\
\text { m-11.00 m }\end{array}$ & $\begin{array}{l}\text { Unit weight }(\gamma)=20 \\
\mathrm{kN} / \mathrm{m}^{3} \\
\text { Saturated unit weight } \\
\left(\gamma_{\text {sat }}\right)=21 \mathrm{kN} / \mathrm{m}^{3}\end{array}$ & $\begin{array}{l}\text { Friction angle }(\Phi)=20^{\circ} \\
\text { Unconfined compressive } \\
\text { strength }\left(\mathrm{q}_{\mathrm{u}}\right)=180 \mathrm{kN} / \mathrm{m}^{2}\end{array}$ \\
\hline \multicolumn{3}{|l|}{ Sand } \\
\hline $\begin{array}{l}\text { Depth: } 11.00 \\
\mathrm{~m}-13.20 \mathrm{~m}\end{array}$ & $\begin{array}{l}\text { Unit weight }(\gamma)=18 \\
\mathrm{kN} / \mathrm{m}^{3} \\
\text { Saturated unit weight } \\
\left(\gamma_{\text {sat }}=20 \mathrm{kN} / \mathrm{m}^{3}\right.\end{array}$ & $\begin{array}{l}\text { Friction angle }(\Phi)=31^{\circ} \\
\text { Unconfined compressive } \\
\text { strength }\left(\mathrm{q}_{\mathrm{u}}\right)=200 \mathrm{kN} / \mathrm{m}^{2} \\
\text { Standard Penetration Test } \\
\left(\mathrm{N}_{\mathrm{SPT}}\right)=20\end{array}$ \\
\hline \multicolumn{3}{|l|}{ Gravel } \\
\hline $\begin{array}{l}\text { Depth: } 11.00 \\
\mathrm{~m}-23.00 \mathrm{~m}\end{array}$ & $\begin{array}{l}\text { Unit weight }(\gamma)=19 \\
\mathrm{kN} / \mathrm{m}^{3} \\
\text { Saturated unit weight } \\
\left(\gamma_{\text {sat }}=21 \mathrm{kN} / \mathrm{m}^{3}\right.\end{array}$ & Friction angle $(\Phi)=45^{\circ}$ \\
\hline
\end{tabular}

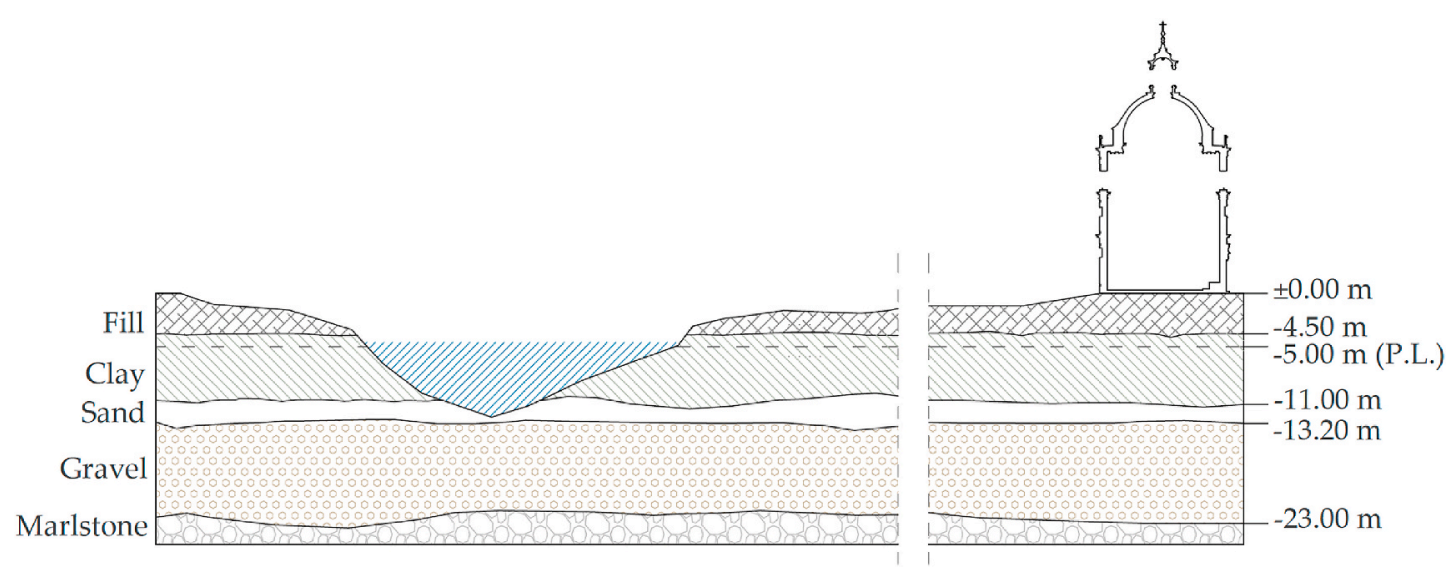

Fig. 3. Soil identifications: geological and geotechnical levels, depth in metres. P.L.: phreatic level. 


\section{DOCUMENTARY STUDIES}

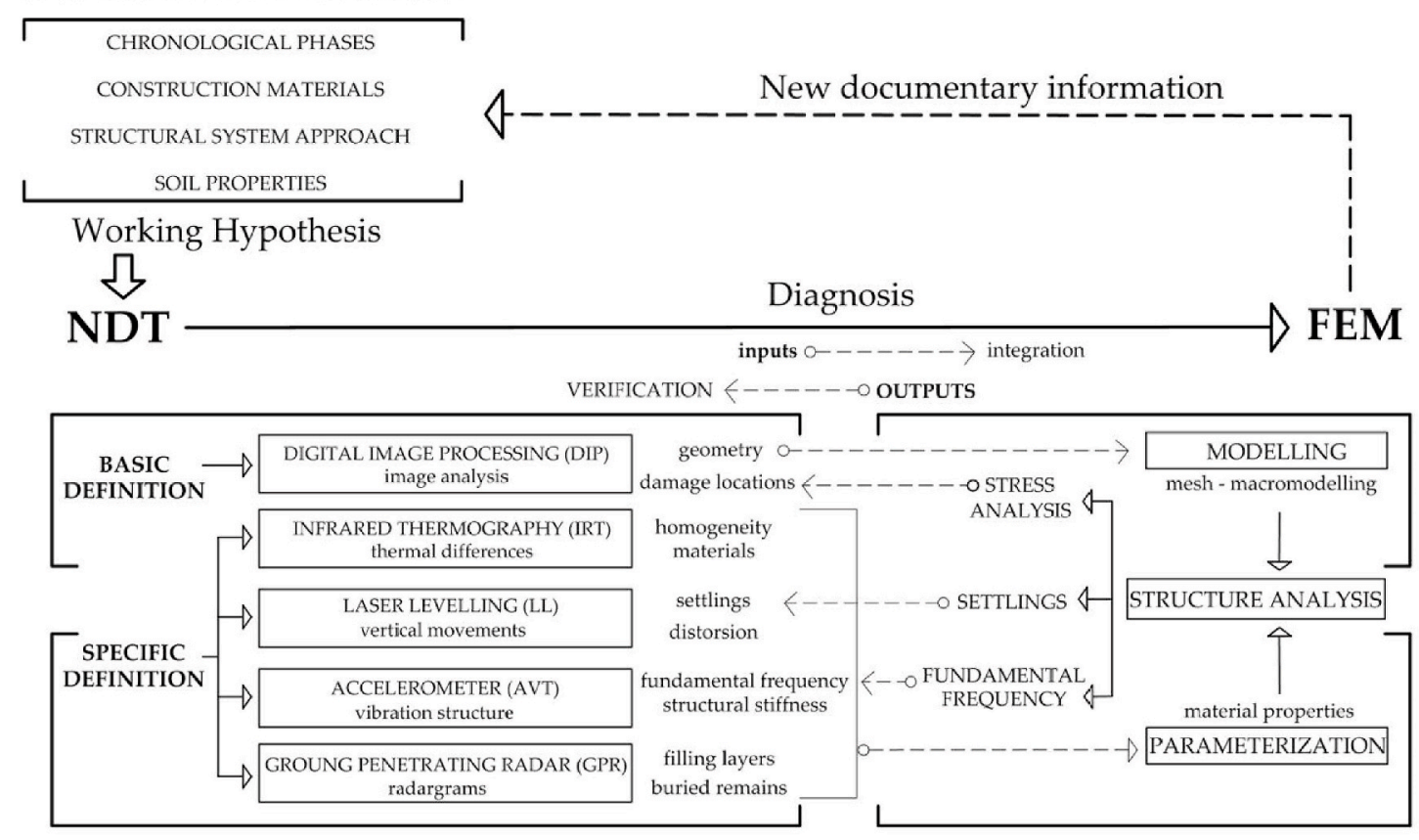

Fig. 4. Integrated NDT and FEM global methodological process.

specific definition: determination of damaged elements and formulation and hypotheses relating to risk situations; FEM simulation: numerical testing of the hypotheses formulated.

Therefore, it is considered that the results of the NDT tests can be used not only to establish a diagnosis of the detected damage, but also to verify the validity of the numerical data used in the development of a simplified calculation model that is capable of complementing the diagnosis made through the use of non-invasive tests, as well as to integrate some of the results into the FEM simulation model itself.

\subsection{NDT implementation process}

Given the extensive overview of the variety of non-destructive techniques that can be applied in the current context, their combination allows for the coherent development of a protocol to evaluate the state of conservation of historic buildings. Additionally, the use of NDT must consider the study of the documentary information on the building which, in many cases, provides data from destructive tests performed in previous historical stages [51].

The application of several of the techniques employed has been carried out through the researchers' methodologies, in an effort to obtain scientific results in the most rigorous, effective, and economical way possible, while still taking into account the needs of financial efficiency, that also require the diagnostic work of pre-existing buildings. In the sections corresponding to the referred cases, the advantages and particularities of the specific methodologies have been laid out and explained.

A complete survey including NDT, such as Digital Image Processing (DIP), Infrared Thermography (IRT), laser levelling (LL), Ambient Vibration Testing (AVT), and geophysical techniques such as GroundPenetrating Radar (GPR), has been carried out. The tests using NDT allow for the characterisation and diagnosis of the building, and at the same time enable the estimation of certain parameters to be taken into account in the simulation of structural aspects using FEM. Together these are employed to validate previous hypotheses and to carry out partial diagnoses. The use of all of them and the superposition of the results that they can contribute provide a comprehensive vision of the current state, by establishing comparative ranges that determine heterogeneities and constructive failures.

\subsubsection{Digital Image Processing (DIP)}

Digital Image Processing is a technique that currently allows for the detailed geometric characterisation of heritage building models [52] and for the detection of material damage [53,54]. It plots a virtual mesh on the façade, to determine the pictures to be taken (Fig. $5 a$ and b). This survey sets the main architectural patterns and spots the main pathologies (Fig. 5c). During this process, various graphic designs and assisted drawing programs have been used. For instance, the ashlars and damage have been drawn in AutoCAD 2019 version.

Photogrammetry of the façades was used as a support to draw the damage of the chapel. Despite the restorations carried out within the last decade, the stone façades of the building display fissures and cracks involving pilasters, windows, and cornices. Vertical, tilted, and horizontal fissures are spread over the whole surface of each façade (Fig. 6). Ancient damage coexists alongside active issues: the different geometry and nature of the cracks highlight their different origins.

Furthermore, inside the dome and vaults major cracks reveal its instability and potential to collapse due to movement. For this reason, a security net has been installed. Subsequent to this preliminary work, it can be concluded that the building presents undetected and unsolved issues that continue to be currently active.

\subsubsection{Infrared thermography (IRT)}

Infrared Thermography is an NDT widely employed for quantitative and qualitative evaluations for building diagnostics [55]. In heritage architecture, it constitutes a highly valuable tool since it allows for the analysis of the state of conservation of construction materials without using invasive sampling methods. The infrared thermography technique is based on the measurement of the radiant thermal energy distribution that is emitted from a target, and translates this distribution into a visible image [56]. We have used a single-time passive thermal acquisition and measure the radiation intensity, in a qualitative study, to detect anomalies in the walls occurring under normal conditions, and emissivity of 1 has been considered in this case study.

The thermal images of the Tabernacle Chapel, taken with a thermography camera model TROTEC AC080V (spectral range 8-14 $\mu \mathrm{m}$; 


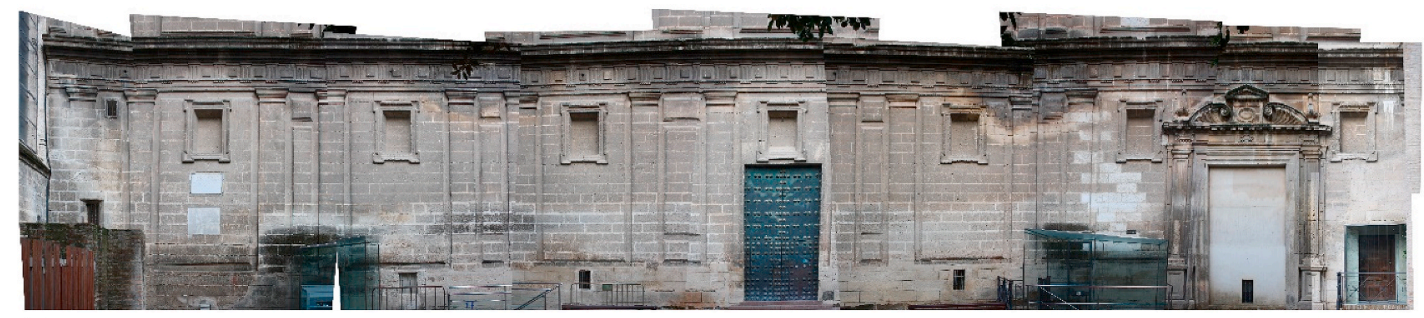

(a)

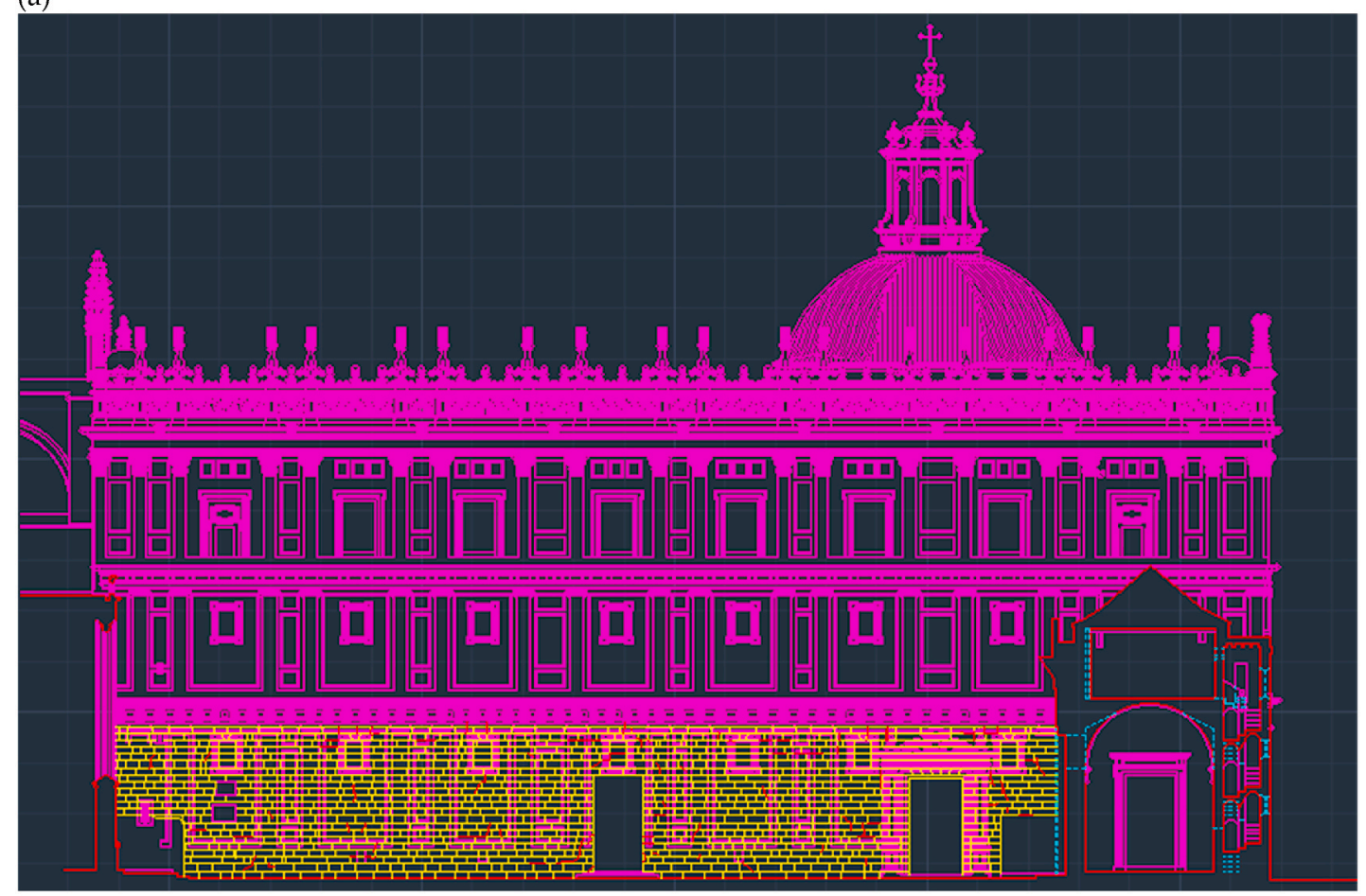

(b)

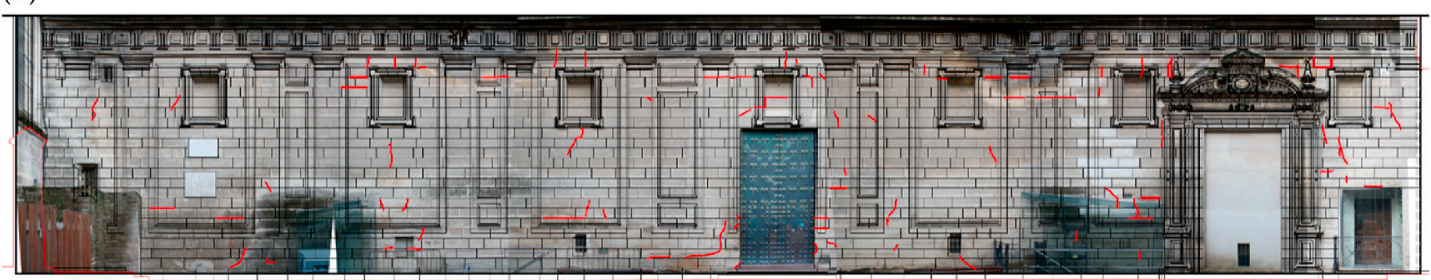

(c)

Fig. 5. Application of DIP to the eastern façade of the Tabernacle Chapel: (a) Photographic set-up of the area analysed (b) Photo-frame drawings using CAD (c) Detailed damage drawing.

LWIR, $160 \times 120 \mathrm{px}$. resolution) have been used for building diagnosis, mainly as a qualitative test, since the objective is the identification of the location of the thermal anomalies, usually due to moisture issues, differences between materials, or wall cracks [57]. Although the measurements can be disturbed by environmental factors, thermal-imaging technology has become a valuable diagnostic tool when locating water filtrations and cracks (Fig. 7). IRT has also been utilised to confirm the non-existence of metallic reinforcements and connectors between the ashlar walls. Moreover, it has enabled the hypothesis to be verified since no abrupt changes in the materials nor transitions between them have been detected.

Capillarity moisture stains have been detected in the north-western corner of the chapel (Fig. 7a). The northern façade displays the main issues with damp. This damage is visible inside the chapel with thermal images. It can be noted that the thermal image of the main vault shows several spots with lower temperatures. These points may be consistent with water leaks caused by cracks in the external masonry (Fig. 7b).
Fig. $7 \mathrm{c}$ shows a spot with a high decrease in temperature, pointing out the existence of a crack that had been located through the visual inspection, which also happens to be a highly tensile spot in FEM.

\subsubsection{Laser levelling ( $L L)$}

Based on the knowledge of various laser-levelling techniques (LL) to determine building movements [58,59], a simplified method has been employed to detect the angular distortions of the structural elements from the measurement of their vertical deformations [60].

Consequently, an accurate levelling of the chapel floor has proved itself to be a very useful tool in assessing building damage. Vertical movements were obtained using a self-levelling laser model BOSCH GLL-80, placed at points near the pilasters and adjacent to the main loading areas. A detailed plan has been plotted with the numerous measurements, as shown in Fig. 8.

The maximum variation of levels is located near the western façade wall, showing around $6 \mathrm{~cm}$ in the north-eastern sector. From this data, 


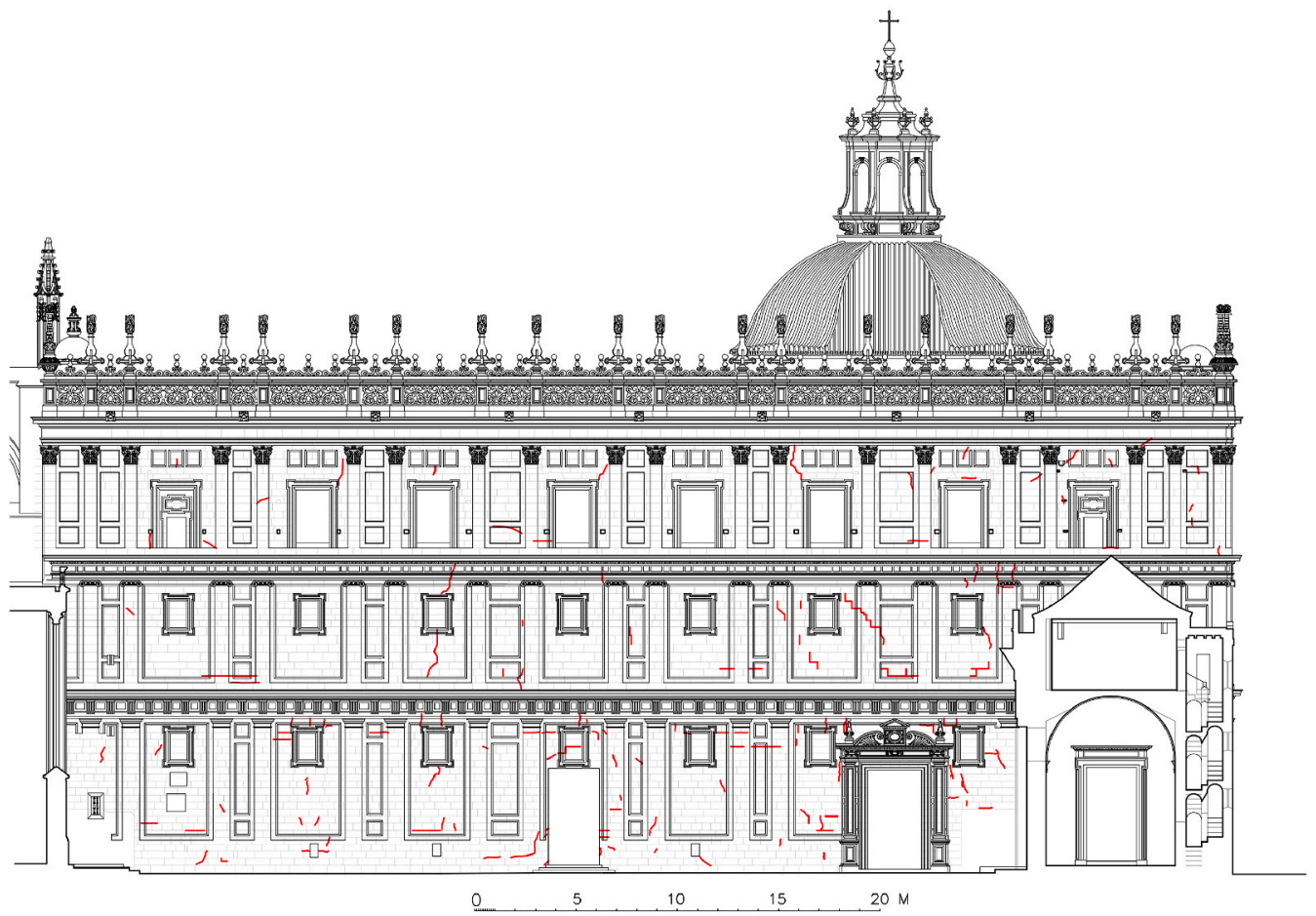

Fig. 6. Example of damage survey of the eastern façade of the Tabernacle Chapel. Identification of cracks up to $20 \mathrm{~mm}$ in width.

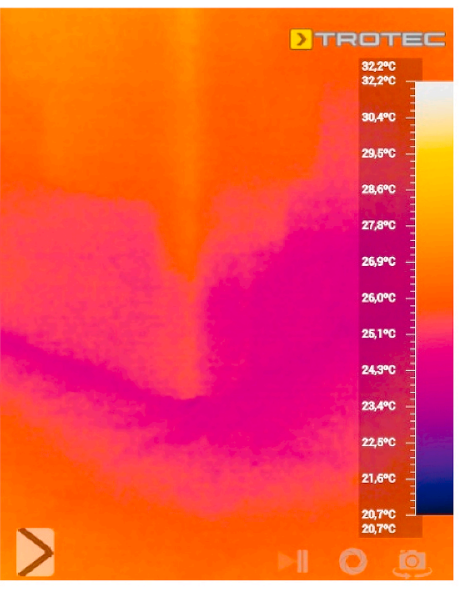

(a)

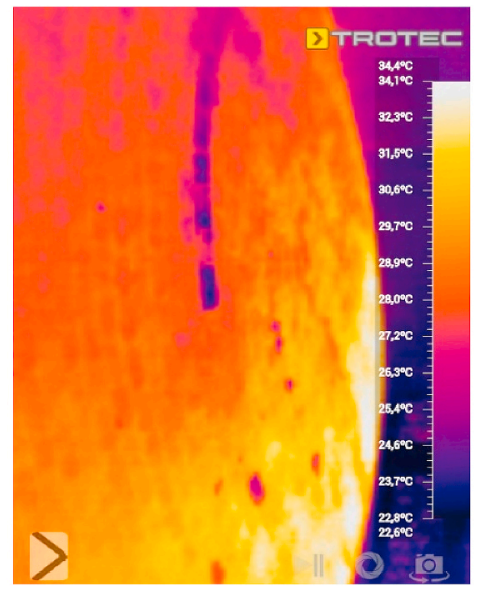

(b)

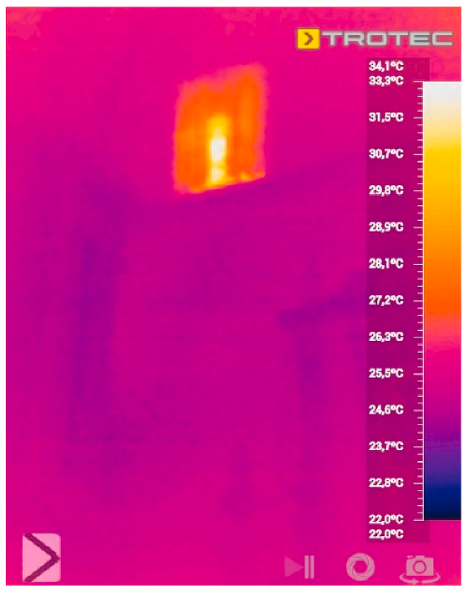

(c)

Fig. 7. IRT images of the Tabernacle Chapel: (a) north-western corner; (b) main vault; (c) north-eastern corner.

the angular distortions triggered by instances of differential settling between the measured points were calculated. The maximum distortion is $0.0039(1 / 256)$, located between the points $\mathrm{A} 2$ and $\mathrm{A} 3$ in the façade (Fig. 8). These methods show the serious settling issues of the façade wall. The settling of the building is not homogeneous as a rigid solid: there are significant differential examples of settling between various areas of the walls.

\subsubsection{Ambient Vibration Testing (AVT)}

Ambient Vibration Testing is employed to determine the rigidity of a structure in situ. This test is based on obtaining the measurement of the movement or vibration generated by the external sources of vibration. All systems undergo a series of environmental actions (wind, traffic, human activity) that generate a response in the form of oscillation or vibration, which, as the product of these external actions, is called environmental vibration. Knowledge regarding the way in which the structure responds allows its fundamental period or frequency to be estimated with sufficient precision: information from which it is possible to determine the rigidity and consequently the bracing degree of the structure studied [61]. The result of this test, the vibration fundamental period of the structure [62], means that an estimate of its overall structural rigidity can be made, thereby providing an empirical value with which to evaluate its state of conservation, because this fundamental period $(\mathrm{T})$ is related to the rigidity $(\mathrm{k})$ and total mass $(\mathrm{m})$ of the structure (Equation (1)).

$T=2 \pi \sqrt{\frac{m}{k}}$

Compared to the use of other methods, such as forced or induced vibration, environmental vibration presents significant advantages, such 


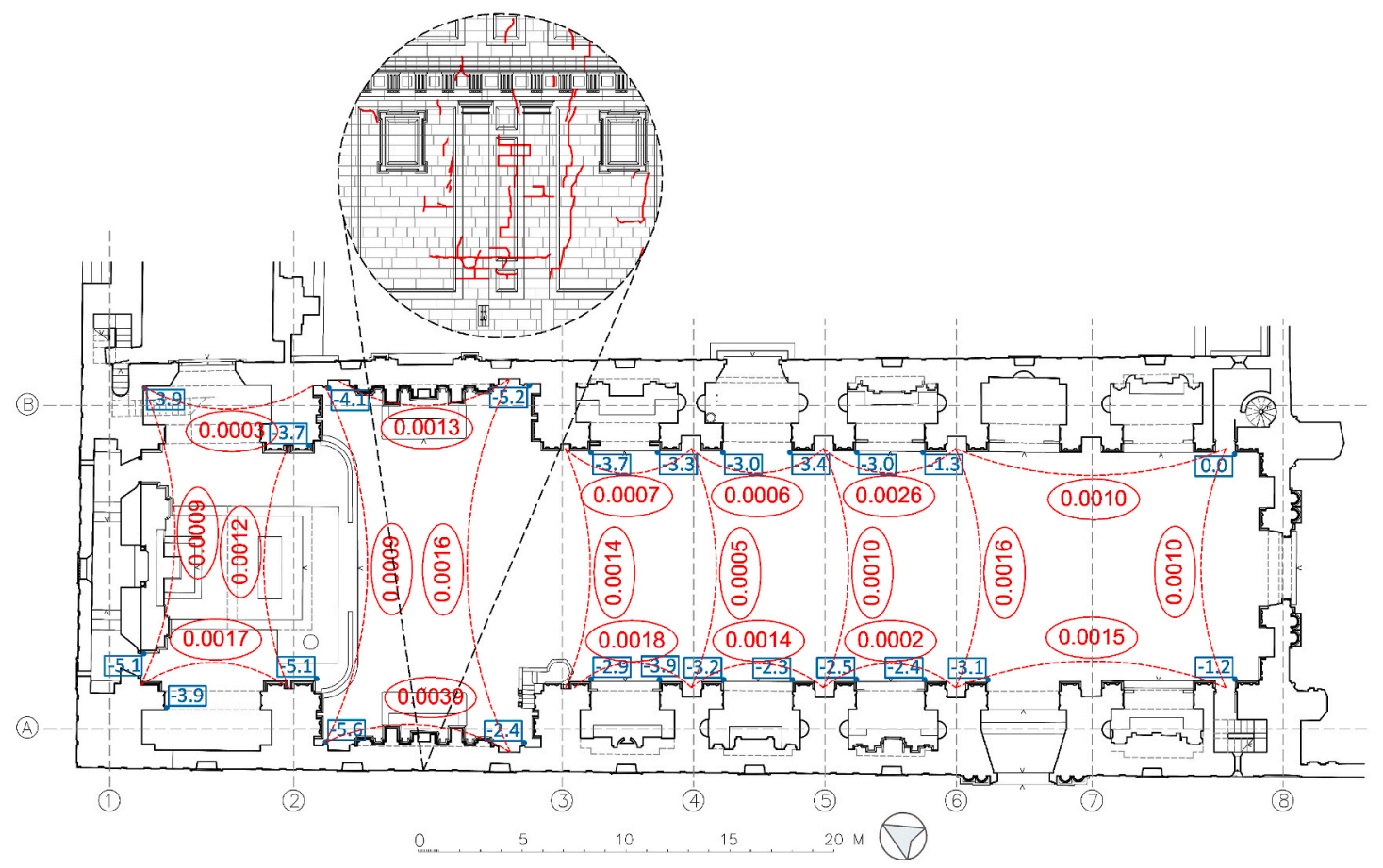

Fig. 8. Plan showing levelling in centimetres (blue rectangles) and angular distortions (red ellipses).
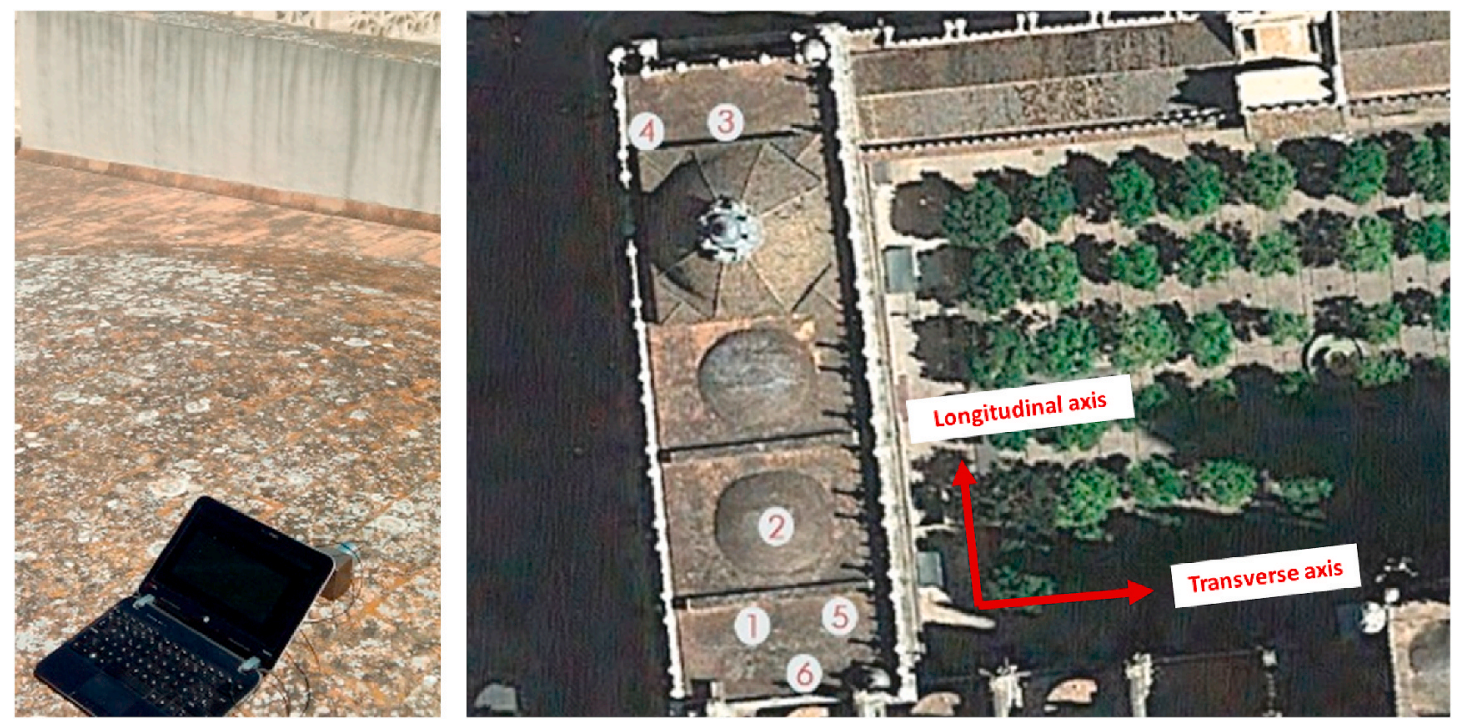

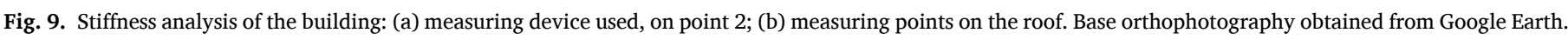

as efficiency, speed, and economy, in addition to not running any risk since no type of stress is exerted on a structure that could be in a poor condition, which would otherwise pose a risk to both the people performing the test and the structure itself. The results obtained in various experiments show that the use of environmental vibration to obtain the fundamental period of a structure and other dynamic characteristics is sufficiently precise [63].

The test is carried out by means of an accelerometer, which is a device capable of measuring these small oscillations imperceptible to humans. The data emitted by the accelerometer is filtered through an analogue-digital converter, which, through the appropriate software, enables this data to be collected by a laptop computer, thereby providing the natural frequency of vibration of the building through the analysis of the registered signal. Stiffness analysis of the structure is carried out using a high-sensitivity MMF uniaxial accelerometer (model KB12VD) to gauge the ambient vibration of the structure in each of the monitoring zones selected. This accelerometer has a bandwidth range of $0.08-4000$ $\mathrm{Hz}$, a dynamic range of \pm 0.5 to $\pm 5 \mathrm{~g}$, a sensitivity of $10000 \mathrm{mV} / \mathrm{g}$, a resolution of $8 \mathrm{mg}$ and $210 \mathrm{~g}$ weight, connected by coaxial cables to a system of Front-end data acquisition with a 24-bit ADC. In order to facilitate contact of the accelerometers with the building surface, epoxy contact resin was placed on the base.

The results obtained have been verified by taking several measures at different places of the walls. Two measurements were taken at all points: one parallel to the longitudinal direction of the church nave and the other perpendicular to it. The test was carried out at six points on the structure (Fig. 9) in order to obtain general information on the building, thereby ruling out any distortion of the measurement due to the 
Table 5

Accelerometer measurement results.

\begin{tabular}{|c|c|c|c|c|c|}
\hline \multicolumn{2}{|c|}{ Measurement Point } & \multicolumn{2}{|c|}{ Longitudinal axis } & \multicolumn{2}{|c|}{ Transverse axis } \\
\hline & & $\mathrm{F}(\mathrm{Hz})$ & $\mathrm{T}(\mathrm{s})$ & $\mathrm{F}(\mathrm{Hz})$ & $\mathrm{T}(\mathrm{s})$ \\
\hline 1 & Longitudinal end of the building & 11.04 & 0.09 & 7.06 & 0.14 \\
\hline 2 & Upper part of the vault & 9.18 & 0.11 & 5.27 & 0.19 \\
\hline 3 & Longitudinal end of the building & 3.21 & 0.31 & 5.67 & 0.18 \\
\hline 4 & Possible foundation settling & 6.99 & 0.14 & 7.88 & 0.13 \\
\hline 5 & Vertical crack & 2.22 & 0.45 & 5.27 & 0.19 \\
\hline 6 & Vertical crack & 4.61 & 0.22 & 3.12 & 0.32 \\
\hline
\end{tabular}

presence of injuries. Thus, the choice of measurement points 1 and 3 is due to the fact that these are points located at either end of the nave in a longitudinal direction, and they would therefore provide relevant information for the analysis of the overall behaviour of the whole building. If the results are very similar, then it can be stated that the building responds in a unique way as a rigid solid.

Otherwise, there would be parts that move independently to those of the rest, which would indicate the existence of pathologies that affect the overall rigidity. For the purposes of comparison, point 2 is located in the upper part of one of the chapel's vaults. This is a different construction element from the rest of the building and therefore the result of the measurement should indicate a different response. Point 4 is located on the vertical of the façade wall of the Constitución Avenue, where it is suspected that there is settling in the foundation. In the same way, the choice of the location of points 5 and 6 is due to the existence of a notable vertical crack in the wall of the Tabernacle Chapel that reveals its resistance against the thrust it receives from one of the buttresses of the Cathedral. Table 5 shows the results obtained from the measurement points.

It can be observed from the values shown at point 2 that the response values differ from those obtained in the other measurement areas. On the other hand, the comparison between points 1 and 3 indicates a major difference in rigidity between the longitudinal ends of the building, with the area where point 3 is located being much less rigid than the area of point 1 in the longitudinal direction (Fig. 10). This difference, albeit less pronounced, persists in the transversal direction.

With regard to the remaining points analysed, the presence of vertical cracks in the walls is reflected in the increase in the fundamental longitudinal period at points 5 and 6 , which is more than double that at point 1 . Likewise, the increase in the fundamental longitudinal period at point 4 with respect to point 1 , despite its spatial proximity, shows the incidence in rigidity of damage due to settling.

In order to compare the results obtained empirically, a theoretical estimate of the fundamental periods and frequencies of the structure has been made. To this end, on the one hand, an empirical formulation proposed by certain regulations is used and, on the other hand, a modal analysis is carried out based on the Finite Element Model described in Section 3.2.

Structural codes of certain countries include empirical formulas that allow the estimation of the fundamental period of load-bearing wall structures [64]. These are expressions that are obtained based on the most common construction systems used in each country. These expressions are useful to compare the theoretical value obtained with this formulation with respect to the empirical values of the measurements taken of the building. The following expression is proposed in the Spanish Seismic-Resistant Standard (NCSE-02) as well as in the Environmental French Code, where TF corresponds to the natural period, $\mathrm{H}$ is the height of the wall, and L is its length (Equation (2)):

$T_{F}=0.06 \cdot H \cdot \sqrt{H /(2 L+H)} / \sqrt{L}$

For the purposes of the analysis, two verifications are carried out. On the one hand, the longitudinal dimension (Lx) of the building is taken into account, while on the other hand, the transversal direction (Ly) is considered. The results obtained with the application of this empirical formula are indicated in Table 6 . The results obtained clearly show the influence of the dimensions of the different panels on the fundamental period of the wall structures.

On the other hand, based on the modal analysis carried out in the Finite Element Model of the Tabernacle Chapel, a fundamental frequency of $3.38 \mathrm{~Hz}(0.29 \mathrm{~s})$ for the transversal direction (mode 1) and $6.10 \mathrm{~Hz}(0.16 \mathrm{~s})$ for the longitudinal direction (mode 2) has been obtained.

\subsubsection{Ground-Penetrating Radar (GPR)}

The application of geophysical methods, such as Ground-Penetrating Radar, provides highly relevant information regarding subsoil materials without the need for direct alteration of their properties [65]. This NDT has acquired a major standing in the analysis of historical buildings, since it allows a better characterisation of the ground layers and the assessment of foundations and archaeological elements [66-70].

The application of the GPR technique to the case study has been performed with Mala Geoscience equipment, in the form of the Easy Locator model. The use of the MID antenna, with a frequency of 300 $\mathrm{MHz}$ and a depth of $6 \mathrm{~m}$, has confirmed the documentary hypotheses regarding subsoil stratigraphy. Additionally, a SHALLOW antenna, with a frequency of $500 \mathrm{MHz}$ and a maximum depth of $2 \mathrm{~m}$, has identified buried building remains. The existence of the crypt, which partially occupies the subsoil of the Tabernacle Chapel, has conditioned the development of this work. Hence, the longitudinal surveys have been carried out parallel to the façades of the building (Fig. 11b and e), while

Table 6

Fundamental period and frequency of the building along its transverse and longitudinal axes.

\begin{tabular}{llllll}
\hline & \multicolumn{2}{l}{$\mathrm{L}_{\mathrm{x}}=57.20 \mathrm{~m}$} & & \multicolumn{2}{l}{$\mathrm{L}_{\mathrm{y}}=19.60 \mathrm{~m}$} \\
\cline { 2 - 3 } \cline { 5 - 6 } & $\mathrm{F}_{\mathrm{F}, \mathrm{x}}(\mathrm{Hz})$ & $\mathrm{T}_{\mathrm{F}, \mathrm{x}}(\mathrm{s})$ & & $\mathrm{F}_{\mathrm{F}, \mathrm{y}}(\mathrm{Hz})$ & $\mathrm{T}_{\mathrm{F}, \mathrm{y}}(\mathrm{s})$ \\
\hline $\mathbf{H}_{\text {tot }}=\mathbf{2 4 . 5} \mathbf{~}$ & 12.25 & 0.08 & 4.86 & 0.21 \\
\hline
\end{tabular}

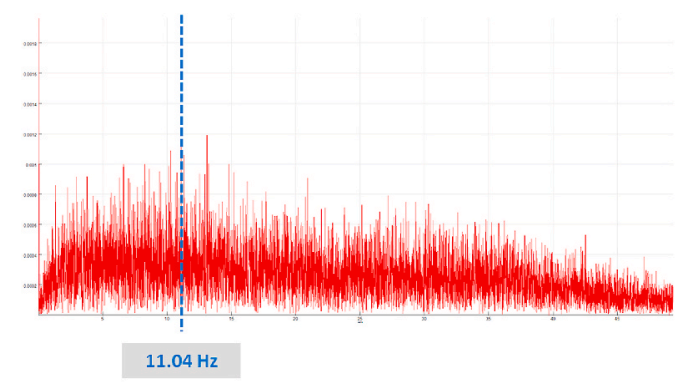

(a)

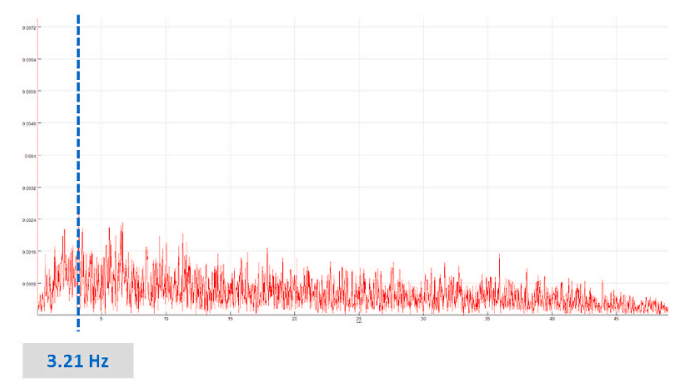

(b)

Fig. 10. Result obtained for the longitudinal fundamental frequency at points 1 (a) and 3 (b). 


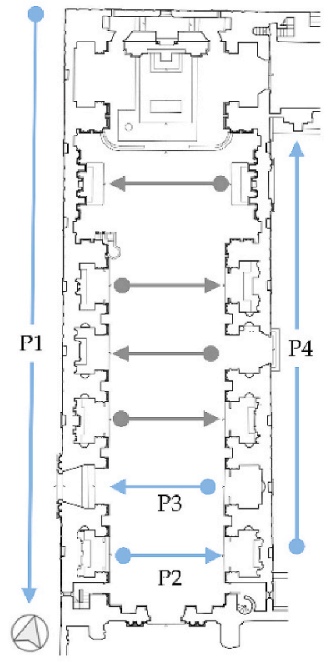

(a)

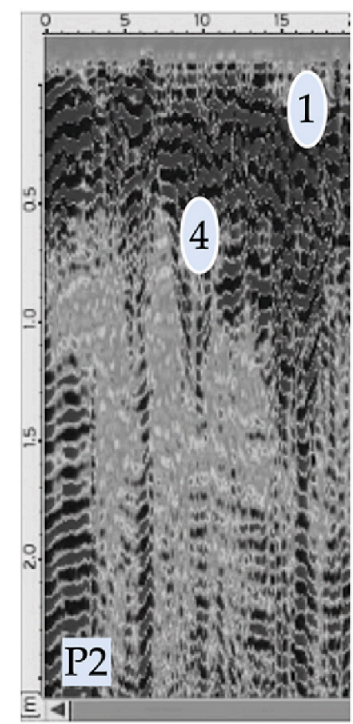

(c)

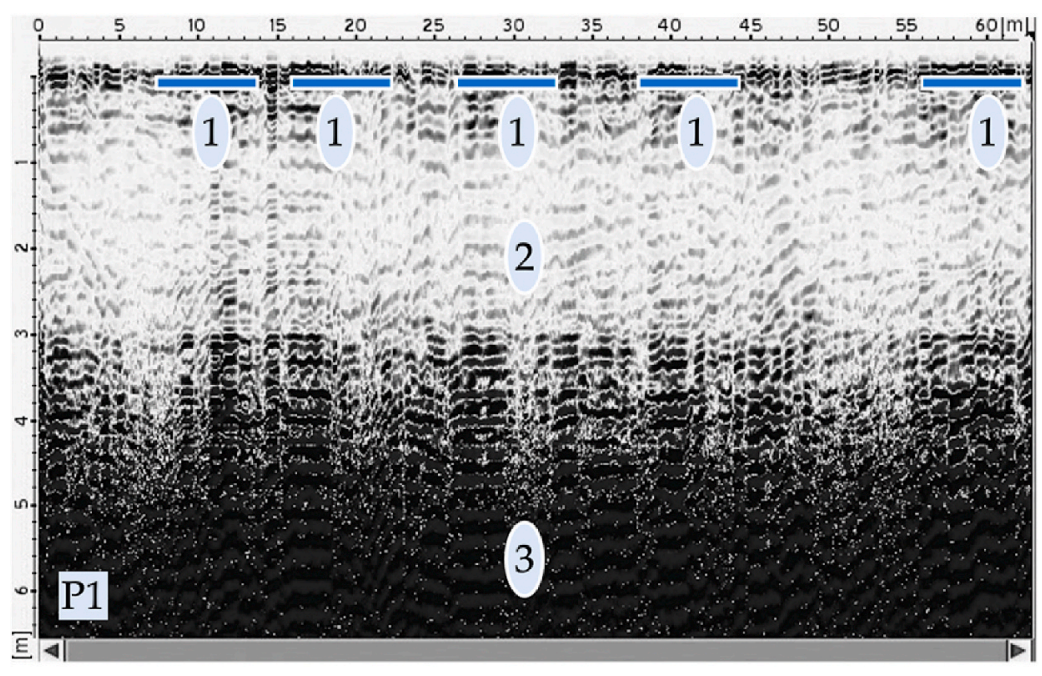

(b)

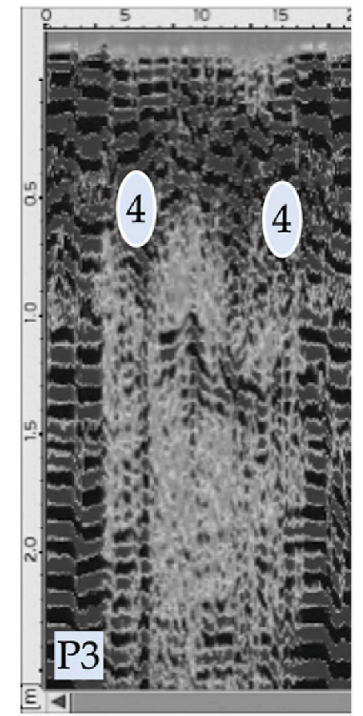

(d)

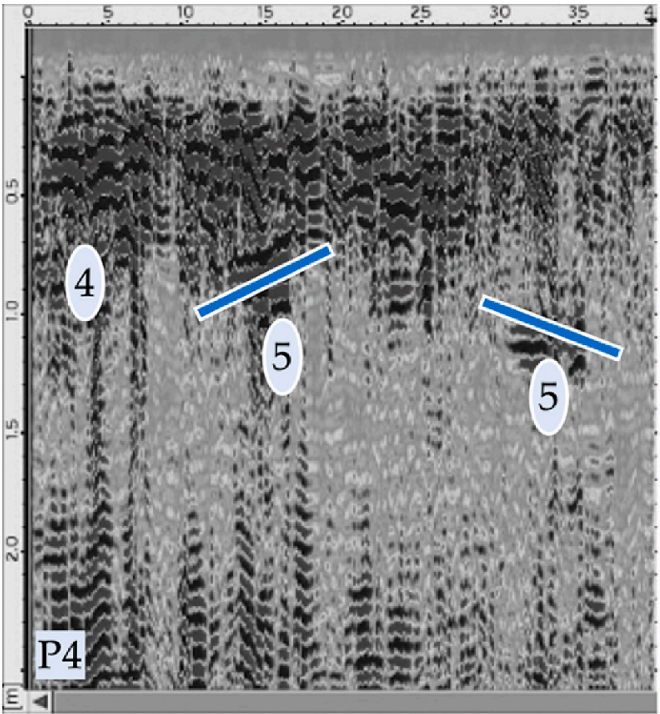

(e)

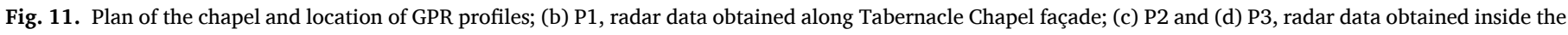
nave; (e) P4, radar data obtained along the eastern façade. (1) Wall foundation (2) Fills (3) Layer of clays (4) Grave (5) Remains of the old Mosque.

the transversal surveys have been carried out inside, within the first sectors of the nave (Fig. 11c and d).

Fig. 11 shows a number of the radar profiles obtained along the façades of the chapel (P1 and P4), and two transversal profiles, which are considered the most significant, from the interior of the nave (P2 and P3).

The GPR data in the P1 profile (Fig. 11b) shows a layer of fill which continues up to the first $4.50 \mathrm{~m}$ of the soil, with an underlying layer of clay underneath. The most significative radar reflection involves the main cavity of this crypt of approximately $5.00 \mathrm{~m}$ wide, located in the left of the image; the sequence of reflections due to the foundations of the walls is also visible. Radar reflections from profiles P2 and P3 also show lateral changes between flooring, the foundation of the walls, and the reflections caused by changes in construction material (Fig. 11 c and d). The profile P4 (Fig. 11e) shows that the possible remains from the ancient foundation can be observed as irregular, low-amplitude reflectors near the surface (from half a metre in depth).

\subsection{A simplified FEM approach to stone masonry buildings}

Regarding the most significant and state-of-the-art investigations into foundation settling in historical stone masonry buildings [71,72], the development of the elastic models through the methodology of finite element calculation is considered valid for its contribution towards understanding the origin of the damage produced in this type of structure. The use of numerical simulations carried out by means of macroelements enables the detection of those parts of the structure that play a fundamental role in the structural behaviour of the building [73].

The model is created by using solid elements whose configuration, however, does not simulate the cutting of the stone masonry blocks [74, 75]. This consideration has always been subject to scientific debate, and specialists, such as Heyman [76], state that this cutting simulation is unnecessary since the size of the blocks in relation to the total volume of the building implies that these blocks behave as one homogeneous mass. In this regard, Heyman's theory breaks with the traditional methods of designing masonry structures, by establishing simple mechanical hypotheses that allow the implementation of this theory in simulation and 

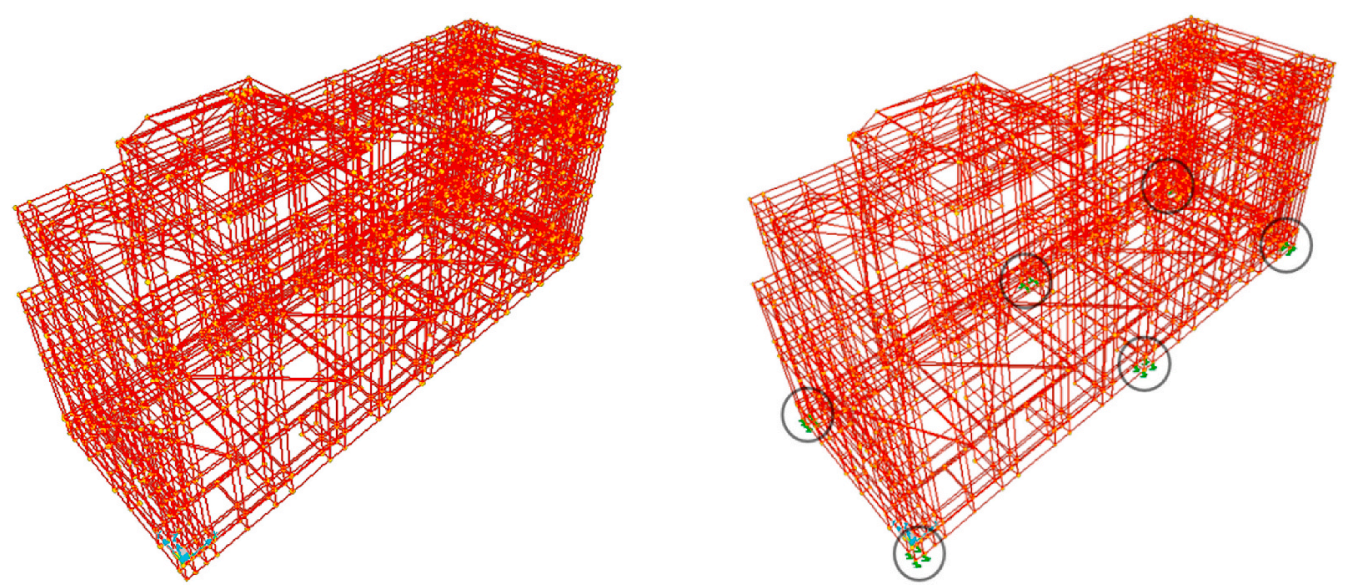

Fig. 12. 3D mesh model from SAP2000 software with springs simulating the settling of the foundations.

structural calculation programs [77]. Ianuzzo et al. [78] have addressed the analysis and identification of fractures of certain loaded masonry structures, and of actions such as settling or distortion, and have identified the material as having normal stress-free rigidity (NRNT), which is treated as a continuous body by Heyman [76]. In contrast, other opinions recognise the geometry of the joints between blocks in the union between the fissures [72]. In this case, it is not intended to reproduce the exact behaviour of the break in the masonry, but rather to promptly develop a model that acts as a complementary verification within a more complete set of diagnostic tests. This criterion leads to simplified modelling that omits the internal configuration of the blocks in the model. In this way, the geometry of the blocks provided in the model adjusts to the sections marked by the chapels and the openings.

\subsubsection{FEM model design}

A Finite Element Model of the structure using the SAP2000 software has been performed to check the failure mechanisms and critical points. The model provides stress values in structural elements of the building in an effort to determine whether any of them exceed the safety limits. Once the settling has been measured, this data is introduced into the SAP2000 software, thereby building a 3D model of the chapel that considers its real deformation, through the integration of both techniques (NDT and FEM) proposed in the methodology. Solid elements have been used in the model. These types of elements use a general three-dimensional formulation, and include the effects of torsion, axial deformation, biaxial bending, and shear deformations.

In accordance with the building's dimensions and the degree of detail required for the results to be interpreted within the global framework of the protocol developed herein, the decision was made to undertake this work through a process of macro modelling [79]. This aspect has mainly affected the geometry of the solid units (which do not correspond to the stone modules but instead to the load-bearing wall sections) and the geometric definition of vaults and domes, which has been simplified. Additionally, it must be borne in mind that the parametric information introduced in the model is derived from the tables provided in the documentary analysis, and from the verification of those values through the application of the different NDTs to the case study, which highlight the characteristics of materials and soil.

At the initial stage, the degrees of freedom in each node are defined, and the displacement and rotation of each node is set, depending on whether it is a fixed or a pinned node. The rotation is restrained about the 3 axes, as are translations 1 and 2, and hence the node can move along the z-axis, along which the required settling is introduced. Once the degrees of freedom have been defined, the vertical movement in each node can be introduced, with the movement obtained from the Surfer software.

In order to simulate the settling that has been previously measured
Table 7

Overview of the results obtained through the application of the methodology to the Tabernacle Chapel.

\begin{tabular}{|c|c|c|}
\hline Documentary studies & Main results & References \\
\hline Chronological phases & $\begin{array}{l}\text { o Phase 1. Construction of the building: } \\
1617-1660\end{array}$ & [40] \\
\hline Construction materials & $\begin{array}{l}\text { o Phase 2. Interventions: } 1660-2020 \text {. } \\
\text { o Unconfined compression tests. } \\
\text { o Samples from the walls qu }=2.70 \mathrm{MPa} \text {. } \\
\text { o Samples from the foundation qu }=1.20 \\
\text { MPa. }\end{array}$ & [41-46] \\
\hline $\begin{array}{l}\text { Structural system } \\
\text { approach }\end{array}$ & o Geometric and structural ratios. & [47] \\
\hline Soil properties & $\begin{array}{l}\text { o Layers: thickness and mechanical } \\
\text { properties. }\end{array}$ & {$[48,49]$} \\
\hline $\begin{array}{l}\text { NDT Test: basic } \\
\text { definition }\end{array}$ & Main results & References \\
\hline $\begin{array}{l}\text { Digital Image } \\
\text { Processing (DIP) }\end{array}$ & $\begin{array}{l}\text { o Detailed verification of building } \\
\text { dimensions. } \\
\text { o Damage location: Fissures }>20 \mathrm{~mm} \text {; } \\
\text { Moisture stains. }\end{array}$ & [52-54] \\
\hline $\begin{array}{l}\text { NDT Test: specific } \\
\text { definition }\end{array}$ & Main results & References \\
\hline $\begin{array}{l}\text { Infrared } \\
\text { Thermography (IRT) }\end{array}$ & $\begin{array}{l}\text { o Location points with thermal } \\
\text { differences. } \\
\text { o Water leaks caused by cracks. } \\
\text { o Capillarity moisture stains in walls. }\end{array}$ & [55-57] \\
\hline $\begin{array}{l}\text { Laser Levelling (LL)/ } \\
\text { Distortions }\end{array}$ & $\begin{array}{l}\text { o Maximum settling } 6 \mathrm{~cm} \text {, located in the } \\
\text { north-eastern area } \\
\text { o Maximum distortion } 0.0039(1 / 256) \text {. }\end{array}$ & [58-60] \\
\hline $\begin{array}{l}\text { Ambient Vibration } \\
\text { Testing (AVT) }\end{array}$ & $\begin{array}{l}\text { o Fundamental frequency of the building } \\
\text { between } 10 \text { and } 12 \mathrm{~Hz} \text {. }\end{array}$ & [61-64] \\
\hline $\begin{array}{l}\text { Ground Penetrating } \\
\text { Radar (GPR) }\end{array}$ & $\begin{array}{l}\text { o Verification of the filling layer } \\
\text { thickness. } \\
\text { o Probable location of the remains of the } \\
\text { foundation of the ancient mosque. }\end{array}$ & [65-70] \\
\hline FEM simulation & Main results & References \\
\hline Structural calculation & $\begin{array}{l}\text { o Mechanical tensioning in the central } \\
\text { areas of the façades. } \\
\text { o Higher mechanical tensioning matching } \\
\text { the settling of the foundations. } \\
\text { o Maximum mechanical tensioning } 181 \\
\text { kPa. }\end{array}$ & [71-79] \\
\hline
\end{tabular}

by laser levelling, springs are introduced in strategic nodes with a resistance that triggers the measured displacement. Springs have been introduced in the corners of the chapel and the central nodes of the lateral walls. The translation along the $\mathrm{z}$-axis applied to the southern nodes is four times greater than that in the nodes of the northern side, 

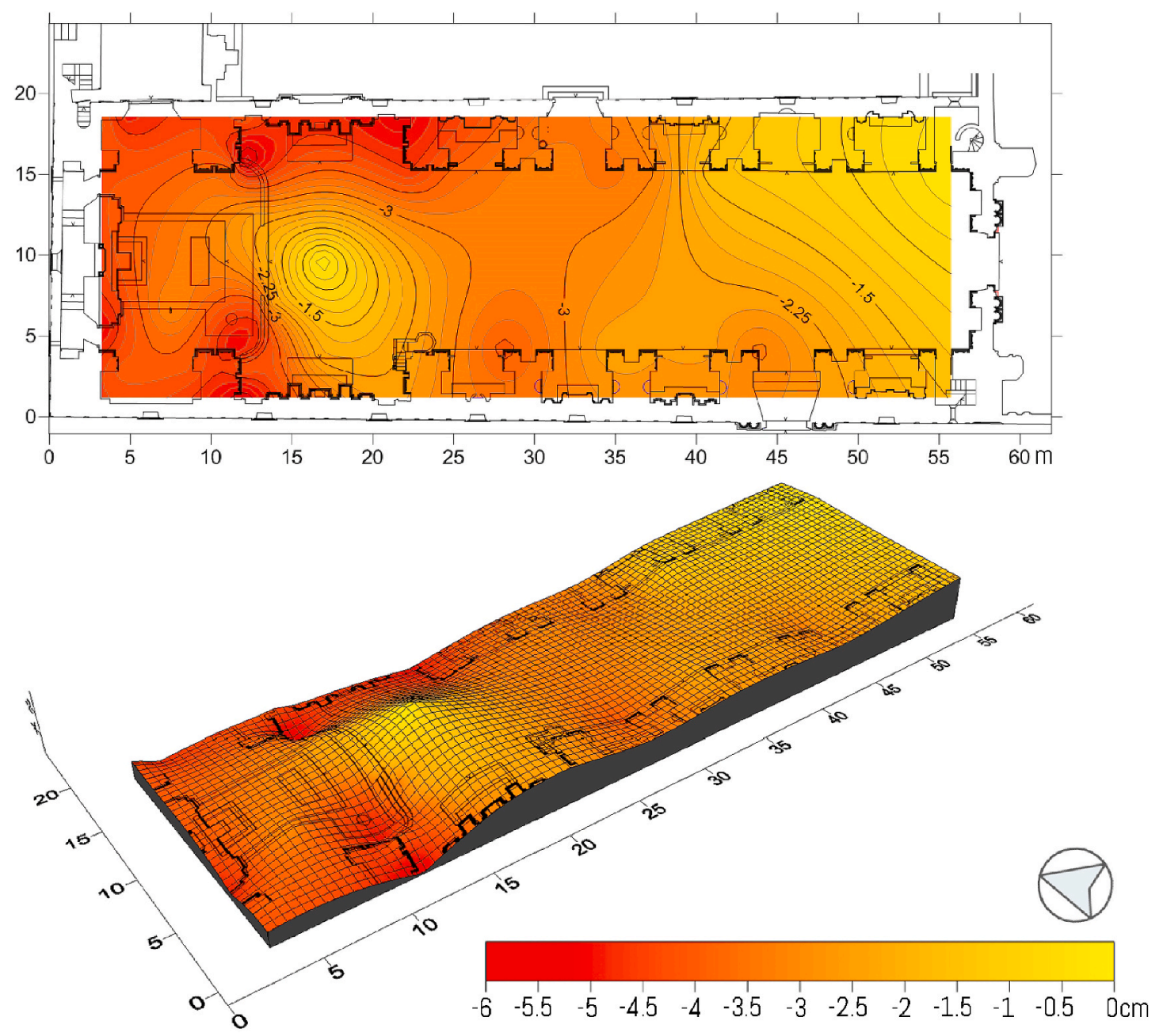

Fig. 13. $2 \mathrm{D}$ and $3 \mathrm{D}$ models showing the settling in the Tabernacle Chapel.

and it is double that of the nodes in the central area, according to the settling measured in the chapel (Fig. 12). In this way, a number of the results measured by the NDTs are integrated into the FEM model.

\section{Results}

The results obtained from the application of the proposed protocol have provided a detailed localisation and characterisation of the main lesions found in the current building, without the necessity of destructive testing (Table 7).

The information gathered has enabled the main causes of the issues to be established, possible future interventions to be evaluated, and preventive conservation actions to be supported for the Tabernacle Chapel. The results achieved for the diagnosis of the building are listed below.

\subsection{Building characterisation}

After having provided a detailed description of the experimental work, its interpretation can be laid out, and conclusions can be drawn [80]. By taking into consideration the results gathered from the aforementioned tests, an evaluation of the building is carried out to ascertain the most critical areas [81].

The results from the application of DIP indicate that the main cause of the damage involves the differential settling of the foundations of the chapel. In the following sections, this hypothesis is verified.

Based on the plot of the floor levelling, a 3D model of the floor has been produced to determine the relative elevation inside the chapel. The three coordinates of the different points were introduced into the Surfer software, to draw the lines of equal elevation, thereby providing a graphic outline of the deformation of the floor and, consequently, to highlight the settling of walls. The figure below shows one of these images with its graphic scale. The reddish colours show the areas with the greatest settling, while yellow implies less settling (Fig. 13).

In the subsequent stage, the $3 \mathrm{D}$ model is analysed with all the movements of the floor inside the chapel, and the central axis where the points with the greatest settling are located can be highlighted.

\subsection{Structural simulation using FEM}

The simulation carried out via FEM leads to a detailed analysis of the structural behaviour of the building. Once the simulated model has been modified with the characteristics observed during the characterisation process, the results obtained from the program can be verified. The most interesting reading involves the stress diagrams produced in the envelope.

When analysing the façades, stresses in the virtual model can be observed due to the foundation settling. Higher tensions are observed in the central areas of the façades, which match the settling of the foundations (Fig. 14). The direction perpendicular to the tensile tension indicates the focus of the issues, and therefore the model faithfully reflects the movements of the foundation. With these results, measurements taken in situ can be directly compared with those obtained from computer calculations. 


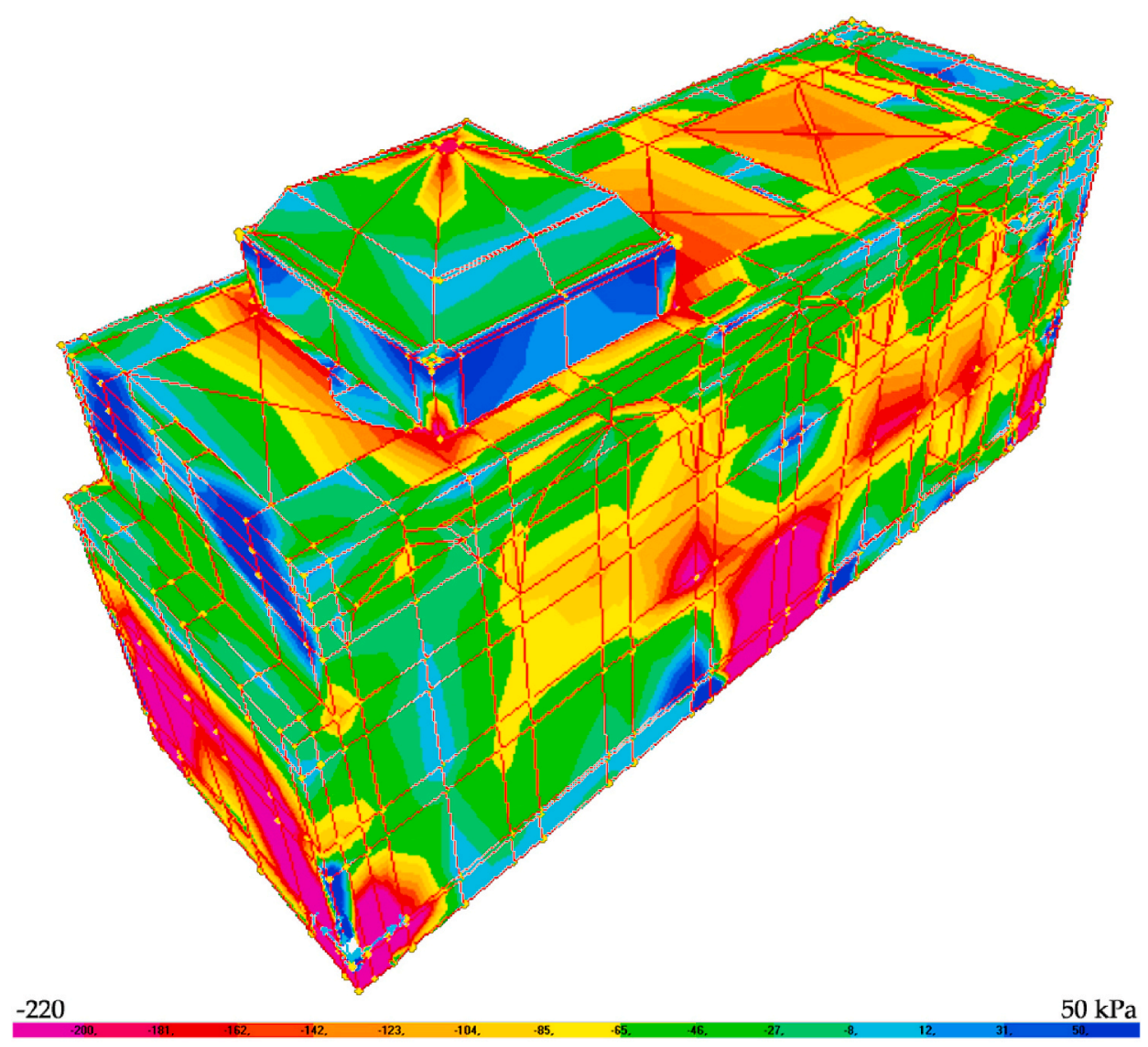

Fig. 14. FEM tensile analysis using SAP2000 software.

After having defined and calculated the model, the results are analysed in order to conclude whether the damage is related to the movements of the soil and whether there is a connection between the cracking and the stress distribution in the model. Through the analysis of the stress distribution in the virtual model due to ground movement and of the cracks located in the façades of the building, a direct correlation is found thereof, which supports the hypothesis. The highest values of stress due to settling are located in the centre of both façades; these values match the areas where the greatest damage is located.

\section{Discussion}

Outcomes of the numerical calculation and data from the building are given in this chapter. Settlement analysis plays an important role in the damage survey. Angular distortion is defined as the differential settling between two points divided by the distance between them. The maximum angular distortion due to the differential settling is 0.0039 (1/ 256) which exceeds the maximum distortion allowed by Spanish regulations [82]. Angular distortion over 1/300 implies damage on building elements and around $1 / 150$ can lead to main structural damage that may affect safety. The cracking of the stone blocks is likely to occur if the angular distortion of the foundation exceeds $1 / 300$. On verifying the damage in the building, the area located between the second and third spaces in the façade is where most of the cracks can be detected, matching with areas with higher vertical deformation values.

Further data has been taken into account; the location of the ancient Aljama mosque beneath the church. The longitudinal section fits perfectly with the supports of the mosque. Data on level curves are superimposed over the plan of the mosque according to the main archaeological hypothesis, in order to find the correlation between the greatest settling and the ancient foundations. Several cross-sections of this 3D model were plotted, as shown in Fig. 15. In this section, the settling of the different points is measured. In these longitudinal sections, the axes of the foundation of the ancient mosque are included. The highest elevation matches the location of one of the supports of the mosque. In Fig. 15, the central section and the plan of the ancient mosque are both sketched [39].

As plotted in Fig. 15, the instances of settling are not homogeneous, and reach their minimum in a specific pillar. One of the supports of the old Aljama mosque is located precisely in this position, which indicates that this pillar was built over the remains of the mosque, while the remaining pillars have yielded on a regular basis. The study shows one of the main issues concerning the Tabernacle is related to the existence of the remains of the old mosque under the chapel.

By visibly overlapping the damage, in terms of cracks, versus stress distribution in each façade, it is possible to observe that the tensile stress coincides with the presence of cracks (Fig. 16).

Fig. 16 integrates the results obtained from the proposed methodological process. Several implemented NDTs are reflected in combination with the results obtained from the FEM model, which together have enabled the real damage to the building to be detected.

Furthermore, the comparison between the data obtained in the empirical measurements of environmental vibration and the results of the theoretical estimates of the period and fundamental frequency have led us to conclude that the building presents damage that causes it to suffer from non-uniform rigidity, especially in the longitudinal direction of the building. The northern area of the Tabernacle Chapel is almost three times more rigid than the southern area. However, a comparison with the theoretical results (empirical values for the period of approximately $0.35 \mathrm{~s}$ as opposed to $0.29 \mathrm{~s}$ obtained in the FEM) allows us to assert that the placement of concrete reinforcement along the crest of the walls during the Menéndez Pidal intervention in 1963 has led to its 

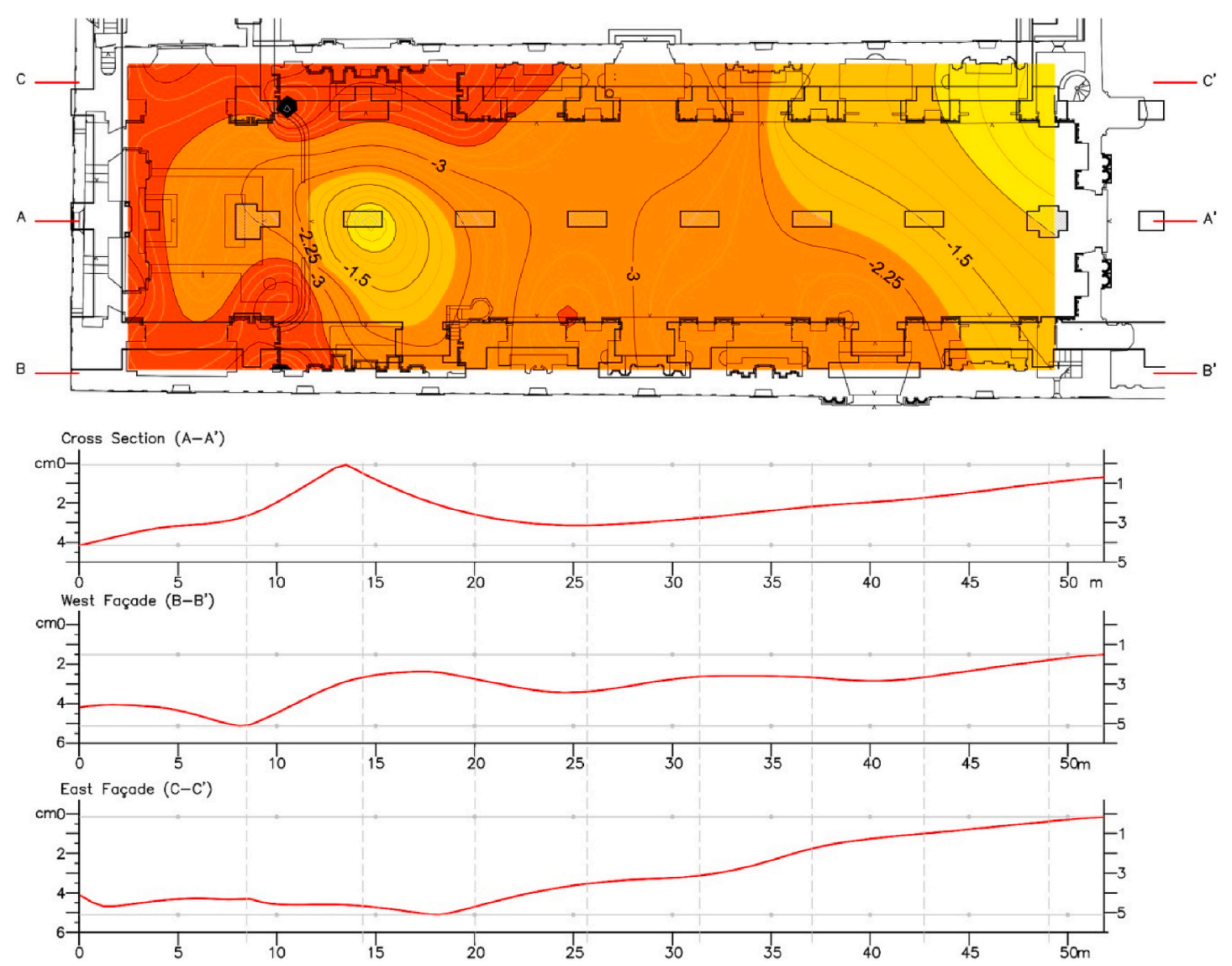

Fig. 15. Floor levelling survey over the ancient mosque plan and longitudinal level sections of the Tabernacle Chapel.

behaviour being successfully stiffened. In spite of this, the analysis shows the need to consolidate the lesions present in the walls. Due to the difference in the architectural periods between the northern and southern areas of the church, its behaviour in the face of certain actions, such as the horizontal actions of an earthquake, would not be homogeneous, which could imply a loss of local stability in certain elements, which could lead to the collapse of part of the structure.

\section{Conclusions}

In this paper, a leading example of architectural heritage with different instances of damage lasting several decades is analysed through an NDT-based methodology. The data gathered has been verified in a Finite Element 1Model built in order to determine the origin of the pathologies. The data measured by means of NDT has been integrated into the simulation model of the structure.

The various steps of the study include: a photographic study of both the exterior and interior façades; plotting of the pathologies in the façades; floor levelling by laser level; the calculation of angular distortions; and the use of tools, such as the study by accelerometer, thermalimaging camera and GPR; and the subsequent verification with the computer 1applications. The combined and integrated use of NDT and FEM not only serves as a resource to establish non-invasive diagnoses in buildings, but it also makes it possible to contribute towards improving the knowledge of historical buildings, since many of these constructions were not as thoroughly documented as are contemporary buildings at the time of their design and subsequent construction. As a result, the data of the physical, geometric, and material properties gathered through sensors, surveys, and calculation models have led to the completion of certain hypotheses that are based on non-primary documentary sources.

These results have led to the identification of critical damage mechanisms. The first and most severe is the deformation of the soil due to the instances of settling that are being produced. The largest instance of settling is of $6.0 \mathrm{~cm}$ in displacement, and is located close to the northwestern area of the building, with an angular distortion of 0.0039 (1/ 256). Consequently, necessary repair measures should be taken. We can therefore conclude that, in the event of an earthquake, the vulnerability of the building would lay in the weakness of the landfills upon which it stands.

On the one hand, reparation work carried out in the church over the years show that the source of the issues is not only the settling of the building, since cracks discovered in the upper level of the longitudinal façades reach thicknesses greater than $20 \mathrm{~mm}$. The existence of the fissures, mainly in the area near the dome of the transept, reveals their thrust on the longitudinal façades. On the other hand, the accelerometer study gauged the lack of stiffness and bracing of the chapel on its longitudinal axis with a fundamental frequency of 10-12 Hz. Hence, the new reinforcing beams should also be placed in the opposing direction, in order for the structure to be completely braced.

The analyses carried out prove there is a way to study heritage architecture without damaging it. The NDT methodology proposed, based on the successive essays brought together in the research, has been proved to be conclusive for detecting the damage focus. In the case of the Tabernacle Chapel in Seville Cathedral, as has been shown previously, the use of non-destructive studies and techniques their subsequent integration into a FEM calculation has largely allowed locating the source of the problems it presents. Until now, the variety of NDTs presented in this research and their consequent integration and validation through FEM had not been used. The use of techniques such as Digital Image Processing or Laser Levelling, very economical and sustainable, has allowed to calibrate the behaviour of the building in the structural simulation exhaustively. In addition, the subsequent overlap of results allows to verify the initial hypotheses. 


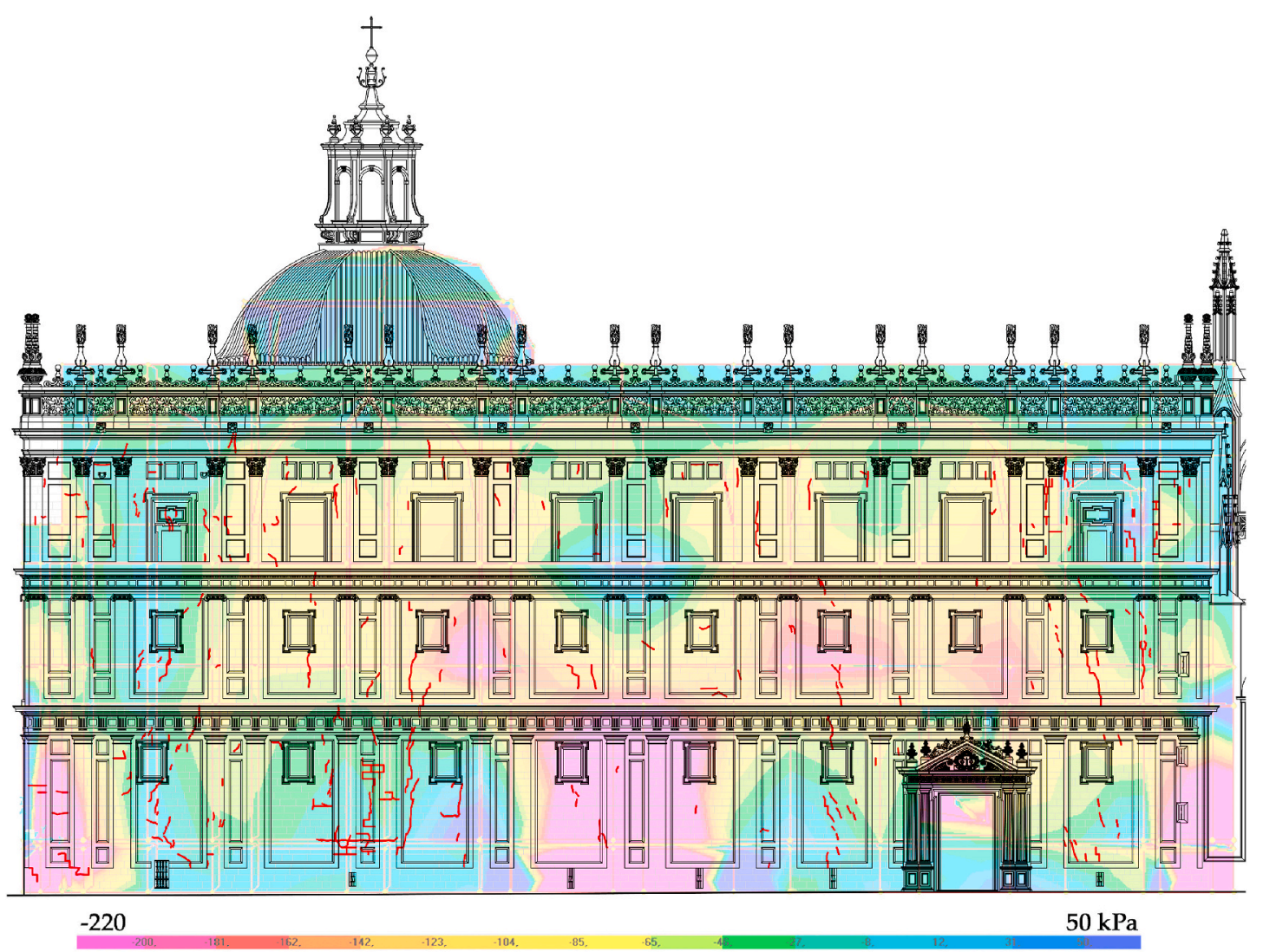

Fig. 16. Tensile stress diagram imposed over the map of fissures in the façade.

Although the experimental procedures described in this research are common in the practice of this type of building diagnosis, the specific characteristics of the building, the sequencing of the tests, and the results obtained all validate a methodology that could be applied to other analyses of architectural heritage refurbishment processes.

\section{Authour contributions}

Conception and design of study: Diz-Mellado and Rivera-Gómez.

Acquisition of data: Diz-Mellado, Romero-Hernández and MascortAlbea

Analysis and/or interpretation of data: Jaramillo-Morilla, GalánMarín, Rivera-Gómez and Ruiz-Jaramillo

Drafting the manuscript: Diz-Mellado, Mascort-Albea, RomeroHernández, Galán-Marín, Rivera-Gómez, Ruiz-Jaramillo, JaramilloMorilla

Revising the manuscript critically for important intellectual content: Diz-Mellado,

Mascort-Albea, Romero-Hernández, Galán-Marín, Rivera-Gómez, Ruiz-Jaramillo, JaramilloMorilla

\section{Declaration of competing interest}

The authors declare that they have no known competing financial interests or personal relationships that could have appeared to influence the work reported in this paper.

\section{Acknowledgements}

The authors wish to acknowledge the IUACC "Instituto Universitario de Arquitectura y Ciencias de la Construcción" for the support necessary to carry out this research. The authors also gratefully acknowledge the financial support of the Spanish Ministry of Education, Culture, and
Sport via a pre-doctoral contract granted to Eduardo Diz-Mellado (FPU 18/04783).

Additionally, the authors would like to thank: D. Jaime Navarro Casas, the architect of the cathedral, for his help in gaining access to the building; $\mathrm{D}^{\mathrm{a}}$ Ana $\mathrm{M}^{\mathrm{a}}$ Bravo Bernal for her in-depth knowledge of this case study; and all names involved in handling the various pieces of equipment. Finally, sincere thanks are expressed to the IDE Seville geographic platform for their permission to publish the urban cartographies employed in the paper.

\section{References}

[1] Y. Ahmad, The scope and definitions of heritage: from tangible to intangible, Int. J. Herit. Stud. 12 (3) (2006) 292-300, https://doi.org/10.1080/ 13527250600604639.

[2] D. Paoletti, D. Ambrosini, S. Sfarra, F. Bisegna, Preventive thermographic diagnosis of historical buildings for consolidation, J. Cult. Herit. 14 (2) (2013) 116-121, https://doi.org/10.1016/j.culher.2012.05.005.

[3] ICOMOS (International Council on Monuments and Sites), Principles for the Analysis, Conservation and Structural Restoration of Architectural Heritage, ICOMOS 14th General Assembly, Victoria Falls, Zimbawe, 2003.

[4] G. Croci, The Conservation and Structural Restoration of Architectural Heritage, Computational Mechanics Publications, Southampton, United Kingdom, 1998.

[5] D. Breysse, X. Romão, M. Alwash, Z.M. Sbartaï, V.A.M. Luprano, Risk evaluation on concrete strength assessment with NDT technique and conditional coring approach, J Build Eng (2020) 32, https://doi.org/10.1016/j.jobe.2020.101541. July 2019.

[6] J. Hola, K. Schabowicz, State-of-the-art non-destructive methods for diagnostic testing of building structures - anticipated development trends, Arch Civ Mech Eng 10 (3) (2010) 5-18, https://doi.org/10.1016/S1644-9665(12)60133-2.

[7] A.D. Styliadis, L.A. Sechidis, Photography-based façade recovery \& 3-d modeling: a CAD application in Cultural Heritage, J. Cult. Herit. 12 (3) (2011) 243-252, https://doi.org/10.1016/j.culher.2010.12.008.

[8] L. Binda, A. Saisi, C. Tiraboschi, Investigation procedures for the diagnosis of historic masonries, Construct. Build. Mater. 14 (4) (2000) 199-233, https://doi. org/10.1016/S0950-0618(00)00018-0.

[9] M. Solla, J.C. Caamaño, B. Riveiro, P. Arias, A novel methodology for the structural assessment of stone arches based on geometric data by integration of 
photogrammetry and ground-penetrating radar, Eng. Struct. 35 (2012) 296-306, https://doi.org/10.1016/j.engstruct.2011.11.004.

[10] A. Saisi, C. Gentile, M. Guidobaldi, Post-earthquake continuous dynamic monitoring of the gabbia tower in Mantua, Italy, Constr Build Mater. 81 (2015) 101-112, https://doi.org/10.1016/j.conbuildmat.2015.02.010.

[11] F. Cerdeira, M.E. Vázquez, J. Collazo, E. Granada, Applicability of infrared thermography to the study of the behaviour of stone panels as building envelopes, Energy Build. 43 (8) (2011) 1845-1851, https://doi.org/10.1016/j. enbuild.2011.03.029.

[12] V. Pérez-Gracia, O. Caselles, J. Clapes, R. Osorio, G. Martínez, J.A. Canas, Integrated near-surface geophysical survey of the Cathedral of Mallorca, J. Archaeol. Sci. 36 (7) (2009) 1289-1299, https://doi.org/10.1016/j. jas.2009.03.001.

[13] A. Moropoulou, K.C. Labropoulos, E.T. Delegou, M. Karoglou, A. Bakolas, Nondestructive techniques as a tool for the protection of built cultural heritage, Construct. Build. Mater. J 48 (2013) 1222-1239, https://doi.org/10.1016/j. conbuildmat.2013.03.044.

[14] Y. El Masri, T. Rakha, A scoping review of non-destructive testing (NDT) techniques in building performance diagnostic inspections, Construct. Build. Mater. 265 (2020) 120542, https://doi.org/10.1016/j.conbuildmat.2020.120542.

[15] E. Mesquita, R. Martini, A. Alves, P. Antunes, H. Varum, Non-destructive characterization of ancient clay brick walls by indirect ultrasonic measurements, J Build Eng 19 (May) (2018) 172-180, https://doi.org/10.1016/j. jobe.2018.05.011.

[16] V. Pérez-Gracia, O. Caselles, J. Clapés, G. Martinez, R. Osorio, Non-destructive analysis in cultural heritage buildings: evaluating the Mallorca cathedral supporting structures, NDT E Int. 59 (2013) 40-47, https://doi.org/10.1016/j. ndteint.2013.04.014.

[17] G. Kilic, Using advanced NDT for historic buildings: towards an integrated multidisciplinary health assessment strategy, J. Cult. Herit. 16 (4) (2015) 526-535, https://doi.org/10.1016/j.culher.2014.09.010.

[18] M.I. Martínez-Garrido, R. Fort, M. Gómez-Heras, J. Valles-Iriso, M.J. Varas-Muriel, A comprehensive study for moisture control in cultural heritage using nondestructive techniques, J. Appl. Geophys. 155 (2018) 36-52, https://doi.org/ 10.1016/j.jappgeo.2018.03.008.

[19] C. Chastre, M. Ludovico-Marques, Nondestructive Testing Methodology to Assess the Conservation of Historic Stone Buildings and Monuments, Elsevier Ltd, 2018, https://doi.org/10.1016/B978-0-08-101928-3.00013-6.

[20] G. Faella, G. Frunzio, M. Guadagnuolo, A. Donadio, L. Ferri, The church of the nativity in Bethlehem: non-destructive tests for the structural knowledge, J. Cult Herit. 13 (4) (2012) 27-41, https://doi.org/10.1016/j.culher.2012.10.014.

[21] F. Gabellone, G. Leucci, N. Masini, R. Persico, G. Quarta, F. Grasso, Non-destructive prospecting and virtual reconstruction of the chapel of the Holy Spirit in Lecce, Italy, Near Surf. Geophys. 11 (2) (2013) 231-238, https://doi.org/10.3997/1873 0604.2012030.

[22] P.B. Lourenço, K.J. Krakowiak, F.M. Fernandes, L.F. Ramos, Failure analysis of Monastery of Jerónimos, Lisbon: how to learn from sophisticated numerical models, Eng. Fail. Anal. 14 (2) (2007) 280-300, https://doi.org/10.1016/j engfailanal.2006.02.002.

[23] S. Bennati, D. Aita, R. Barsotti, et al., Survey, experimental tests and mechanical modelling of the dome of Pisa Cathedral: a multidisciplinary study, Int J Mason Res Innov 5 (1) (2020) 142, https://doi.org/10.1504/IJMRI.2020.104850.

[24] M.-G. Masciotta, J.C.A. Roque, L.F. Ramos, P.B. Lourenço, A multidisciplinary approach to assess the health state of heritage structures: the case study of the Church of Monastery of Jerónimos in Lisbon, Construct. Build. Mater. 116 (2016) 169-187, https://doi.org/10.1016/j.conbuildmat.2016.04.146.

[25] L. Lopez-Gonzalez, R. Otero de Cosca, M. Gomez-Heras, S. Garcia-Morales, A 4D GIS methodology to study variations in evaporation points on a heritage building Environ Earth Sci 75 (14) (2016), https://doi.org/10.1007/s12665-016-5907-8.

[26] G. Kilic, Integrated health assessment strategy using NDT for reinforced concrete bridges, NDT E Int. 61 (2014) 80-94, https://doi.org/10.1016/j. ndteint.2013.10.001.

[27] G. Bartoli, M. Betti, L. Facchini, M. Orlando, Non-destructive characterization of stone columns by dynamic test: application to the lower colonnade of the Dome of the Siena Cathedral, Eng. Struct. 45 (2012) 519-535, https://doi.org/10.1016/j. engstruct.2012.06.024.

[28] P.B. Lourenço, Recommendations for restoration of ancient buildings and the survival of a masonry chimney, Construct. Build. Mater. 20 (4) (2006) 239-251, https://doi.org/10.1016/j.conbuildmat.2005.08.026.

[29] H.S. Sousa, J.D. Sørensen, P.H. Kirkegaard, J.M. Branco, P.B. Lourenço, On the use of NDT data for reliability-based assessment of existing timber structures, Eng. Struct. 56 (2013) 298-311, https://doi.org/10.1016/j.engstruct.2013.05.014.

[30] V. Bosiljkov, M. Uranjek, R.R. Rokožarní, V. Bokan-Bosiljkov, An integrated diagnostic approach for the assessment of historic masonry structures, J. Cult. Herit. 11 (2010) 239-249, https://doi.org/10.1016/j.culher.2009.11.007.

[31] UNESCO World Heritage Committee, Convention Concerning the Protection of the World Cultural and Natural Heritage. Report of Eleventh Session, France, Paris, 1987. http://whc.unesco.org/en/list/383.

[32] E.J. Mascort-Albea, J. Ruiz-Jaramillo, F. López Larrínaga, A de la Peña Bernal, Sevilla, Patrimonio Mundial: guía cultural interactiva para dispositivos móviles, Rev PH 90 (2016) 152-168, https://doi.org/10.33349/2016.0.3778.

[33] J. Ruiz-Jaramillo, A. Jaramillo-Morilla, E.J. Mascort-Albea, Seismic behavior of Mudejar structures, in: REHAB 2014. International Conference on Preservation, Maintenance and Rehabilitation of Historical Buildings and Structures, Green Lines Institute for Sustainable Development, Tomar, Portugal, 2014, pp. 983-992. http s://idus.us.es/xmlui/handle/11441/50811.
[34] A.J. Prieto, A. Silva, J. de Brito, J.M. Macías-Bernal, F.J. Alejandre, The influence of pathological situations on churches' functionality: an approach based on historical records, Int. J. Architect. Herit. (2017) 1-22, https://doi.org/10.1080/ 15583058.2016.1272011.

[35] S.A. Ruffolo, V. Comite, M.F. La Russa, et al., An analysis of the black crusts from the Seville Cathedral: a challenge to deepen the understanding of the relationships among microstructure, microchemical features and pollution sources, Sci. Total Environ. 502 (2015) 157-166, https://doi.org/10.1016/j.scitotenv.2014.09.023.

[36] A.M. Bravo Bernal, G. Ramallo Asensio, Ubicación de La Capilla Del Sagrario de La Catedral de Sevilla Pervivencia y Escenografía. Murcia, Universidad de Murcia. Consejería de Educación y cultura, España, 2003.

[37] A.M. Bravo Bernal, A. Jiménez Martín, El Sagrario, Un Problema y Su Historia Estudio Arquitectónico y Documental de La Capilla Del Sagrario de La Catedral de Sevilla, Universidad de Sevilla, Sevilla, España, 2003.

[38] A. Jiménez Martín, Cartografía de La Montaña Hueca: Notas Sobre Los Planos Históricos de La Catedral de Sevilla, Cabildo Metropolitano de la Catedral de Sevilla, Sevilla, España, 1997.

[39] A. Jiménez Martín, Anatomía de La Catedral de Sevilla, Diputación de Sevilla, Sevilla, España, 2013.

[40] Jiménez Sancho Á, A. Jiménez Martín, La mezquita mayor almohade de Sevilla análisis arqueológico de su construcción, 2016. https://idus.us.es/xmlui /handle/11441/39118.

[41] J.C. Rodríguez Estévez, Los Canteros de La Catedral de Sevilla: Del Gótico Al Renacimiento, Diputación Provincial de Sevilla, Sevilla, España, 1998.

[42] Barrios Padura Á, J. Barrios Sevilla, Estudio de Las Cimentaciones de Edificios Históricos En La Provincia de Sevilla Siglo XII Al XVI, Universidad de Sevilla, Sevilla, España, 2001.

[43] A. Martín Pérez, M. Alcalde Moreno, Morfología macroscópica de alteración de la piedra de la Catedral de Sevilla/España, Mater. Construcción 40 (219) (1990) 5-28. http://hdl.handle.net/11441/17707.

[44] M.Á. Bello López, Caracterización y estado de alteración química de los materiales empleados en la construcción de la Catedral de Sevilla, 1988. http://hdl.handle. net/11441/15517.

[45] R.M. Esbert Alemany, J. Ordaz Gargallo, F.J. Alonso Rodríguez, et al., Caracterización petrofísica y alterabilidad de las piedras de la Catedral de Sevilla, Mater. Construcción 38 (210) (1988) 5-23, https://doi.org/10.3989/mc.1988.v38. i210.835.

[46] Vorsevi Informe, Técnico Relativo a Los Estudios Preliminares de Los Trabajos de Intervención En La Iglesia Colegial Del Divino Salvador (Sevilla, España), España, Sevilla, 2001.

[47] N. Jorquera, J. Ruiz, C. Torres, Analysis of seismic design criteria of santo domingo church, a colonial heritage of santiago, Chile, Rev la Constr 16 (3) (2017) 388-402, https://doi.org/10.7764/RDLC.16.3.388.

[48] E. Soler Arias, R. Huete Fuertes, C. Rodríguez-Liñán, et al., Anejo I.2. Mapa geotécnico Básico de la Ciudad de Sevilla, in: Protocolo de Inspección Técnica de Edificaciones ITE. Sevilla, España: Colegio Oficial de Arquitectos de sevilla, Fundación Fidas, 2005.

[49] C. Oteo Mazo, P. Arozamena, F. Mendaña, R. Álvarez, Geotechnical problems during the soil boring in the Seville underground (Spain), in: Proceedings of the 17th International Conference on Soil Mechanics and Geotechnical Engineering: the Academia and Practice of Geotechnical Engineering, vol. 3, International Society for Soil Mechanics and Geotechnical Engineering (ISSMGE), London, UK, 2009, pp. 2461-2464. https://www.issmge.org/uploads/publications/1/21/ STAL9781607500315-2461.pdf.

[50] X. Romão, E. Paupério, N. Pereira, A framework for the simplified risk analysis of cultural heritage assets, J. Cult. Herit. 20 (2016) 696-708, https://doi.org/ 10.1016/j.culher.2016.05.007.

[51] D.M. McCann, M.C. Forde, Review of NDT methods in the assessment of concrete and masonry structures, NDT E Int. 34 (2) (2001) 71-84, https://doi.org/10.1016/ S0963-8695(00)00032-3.

[52] P.V.V. De Paiva, C.K. Cogima, E. Dezen-Kempter, M.A.G. De Carvalho, L. R. Cerqueira, Intelligent digital built heritage models: an approach from image processing and building information modelling technology, in: VISIGRAPP 2018 Proc 13th Int Jt Conf Comput Vision, Imaging Comput Graph Theory Appl, vol. 4, 2018, pp. 558-565, https://doi.org/10.5220/0006615005580565. Visigrapp.

[53] R.A. Galantucci, F. Fatiguso, Advanced damage detection techniques in historical buildings using digital photogrammetry and 3D surface anlysis, J. Cult. Herit. 36 (2019) 51-62, https://doi.org/10.1016/j.culher.2018.09.014.

[54] R. Perumal, S.B. Venkatachalam, Non invasive detection of moss and crack in monuments using image processing techniques, J Ambient Intell Humaniz Comput (2020), https://doi.org/10.1007/s12652-020-02006-x. Fitzner 2002.

[55] L. Ruiz Valero, V. Flores Sasso, E. Prieto Vicioso, In situ assessment of superficial moisture condition in façades of historic building using non-destructive techniques, Case Stud Constr Mater 10 (2019), e00228, https://doi.org/10.1016/j.cscm.2019. e00228.

[56] G. Leucci, R. Cataldo, G. De Nunzio, Assessment of fractures in some columns inside the crypt of the Cattedrale di Otranto using integrated geophysical methods, J. Archaeol. Sci. 34 (2) (2007) 222-232, https://doi.org/10.1016/j. jas. 2006.04.012.

[57] C. Rodríguez-Liñán, M.J. Morales Conde, P. Rubio de Hita, F. Pérez Gálvez, Inspección mediante técnicas no destructivas de un edificio histórico: oratorio San Felipe Neri (Cádiz), Inf la Construcción 63 (521) (2011) 13-22, https://doi.org/ 10.3989/ic.10.032.

[58] O. Tsareva, N. Pshchelko, V. Glazunov, A. Yugov, Separation of relative deformations of buildings from a general displacement vector of deformation 
Marks, in: B. Anatolijs, V. Nikolai, S. Vitalii (Eds.), Proceedings of EECE 2019, Springer International Publishing, Cham, 2020, pp. 93-102.

[59] M. Wróblewska, Measurement methods of building structures deflections, E3S Web Conf. 36 (2018) 1-8, https://doi.org/10.1051/e3sconf/20183602010.

[60] J. Ruiz-Jaramillo, E.J. Mascort-Albea, A. Jaramillo-Morilla, Proposed methodology for measurement, survey and assessment of vertical deformation of structures, Struct. Surv. 34 (3) (2016) 276-296, https://doi.org/10.1108/SS-02-2016-0006.

[61] F. Espinoza, J.A. Canas, L.G. Pujades, O. Caselles, U. Mena, Utilización de La Vibración Ambiental Como Fuente de Fxcitación Para El Cálculo de Periodos Fundamentales de Edificios, first ed., Ministerio de Fomento; Dirección General del Instituto Geográfico Nacional, Madrid, 2000.

[62] A.K. Chopra, Dynamics of Structures, fourth ed., México D.F.: Pearson, 2014.

[63] L.F. Ramos, L. Marques, P.B. Lourenço, G. De Roeck, A. Campos-Costa, J. Roque, Monitoring historical masonry structures with operational modal analysis: two case studies, Mech. Syst. Signal Process. 24 (5) (2010) 1291-1305, https://doi.org/ 10.1016/j.ymssp.2010.01.011.

[64] M.A. Najafgholipour, M.R. Maheri, H. Darvishi, S.M. Dehghan, A semi-analytical formulation for estimating the fundamental vibration frequency of historical masonry towers, Bull. Earthq. Eng. 17 (5) (2019) 2627-2645, https://doi.org/ 10.1007/s10518-018-00552-6.

[65] H.M. Jol, Ground Penetrating Radar Theory and Applications, vol. 9, First Edit. Elsevier, 2009, https://doi.org/10.1016/B978-0-444-53348-7.00017-X.

[66] N. Masini, R. Persico, E. Rizzo, Some examples of GPR prospecting for monitoring of the monumental heritage, J. Geophys. Eng. 7 (2) (2010) 190-199, https://doi. org/10.1088/1742-2132/7/2/S05.

[67] D. Ranalli, M. Scozzafava, M. Tallini, Ground penetrating radar investigations for the restoration of historic buildings: the case study of the Collemaggio Basilica (L'Aquila, Italy), J. Cult. Herit. 5 (1) (2004) 91-99, https://doi.org/10.1016/j. culher.2003.05.001.

[68] D. Barilaro, C. Branca, S. Gresta, S. Imposa, A. Leone, D. Majolino, Ground penetrating radar (G.P.R.) surveys applied to the research of crypts in San Sebastiano's church in Catania (Sicily), J. Cult. Herit. 8 (1) (2007) 73-76, https:// doi.org/10.1016/j.culher.2006.10.003.

[69] K.C. Lampropoulos, A. Moropoulou, M. Korres, Ground penetrating radar prospection of the construction phases of the Holy Aedicula of the Holy Sepulchre in correlation with architectural analysis, Construct. Build. Mater. 155 (2017) 307-322, https://doi.org/10.1016/j.conbuildmat.2017.08.044.

[70] V. Pérez-Gracia, J.A. Canas, L.G. Pujades, et al., GPR survey to confirm the location of ancient structures under the Valencian Cathedral (Spain), J. Appl. Geophys. 43 (2-4) (2000) 167-174, https://doi.org/10.1016/S0926-9851(99)00056-7.
[71] G. Castori, M. Corradi, A. Borri, R. Sisti, A De Maria, Macro element and dynamic seismic analysis of the medieval government building of Perugia, Italy, Int J Mason Res Innov 4 (4) (2019) 297, https://doi.org/10.1504/IJMRI.2019.102529.

[72] A. Tralli, A. Chiozzi, N. Grillanda, G. Milani, Masonry structures in the presence of foundation settlements and unilateral contact problems, Int. J. Solid Struct. 191-192 (2020) 187-201, https://doi.org/10.1016/j.ijsolstr.2019.12.005.

[73] M. Valente, G. Brandonisio, G. Milani, A De Luca, Seismic response evaluation of ten tuff masonry churches with basilica plan through advanced numerical simulations, Int J Mason Res Innov 5 (1) (2020) 1, https://doi.org/10.1504/ IJMRI. 2020.104849.

[74] S. Galassi, G. Tempesta, The Matlab code of the method based on the Full Range Factor for assessing the safety of masonry arches, Methods 6 (June) (2019) 1521-1542, https://doi.org/10.1016/j.mex.2019.05.033.

[75] G. Tempesta, S. Galassi, Safety evaluation of masonry arches. A numerical procedure based on the thrust line closest to the geometrical axis, Int. J. Mech. Sci. 155 (February) (2019) 206-221, https://doi.org/10.1016/j.ijmecsci.2019.02.036.

[76] J. Heyman, The stone skeleton, Int. J. Solid Struct. 2 (2) (1966) 249-256, https:// doi.org/10.1016/0020-7683(66)90018-7. IN1-IN4, 257-264, IN5-IN12, 265-279.

[77] G. Zuccaro, M. Angelillo, A. Gesualdo, A. Iannuzzo, A. Fortunato, Rigid block models for masonry structures, Int J Mason Res Innov 3 (4) (2018) 349, https:// doi.org/10.1504/IJMRI.2018.10016294.

[78] A. Iannuzzo, F De Serio, A. Gesualdo, G. Zuccaro, A. Fortunato, M. Angelillo, Crack patterns identification in masonry structures with a $\mathrm{C}^{\circ}$ displacement energy method, Int J Mason Res Innov 3 (3) (2018) 295, https://doi.org/10.1504/ IJMRI.2018.093490.

[79] P.B. Lourenço, Computations on historic masonry structures, Prog. Struct. Eng. Mater. 4 (3) (2002) 301-319, https://doi.org/10.1002/pse.120.

[80] C. Rodríguez-Liñán, R. Romero-Hernández, E. Vázquez-Vicente, et al., The materiality in the architecture of the Modern Movement: theoretical and constructive research: structural and foundation analysis, in: Consejería de Cultura y Patrimonio Histórico, ed. Re-HABITAR El Carmen: Un Proyecto Sobre Patrimonio Contemporáneo, vol. I, Instituto. Sevilla, (Spain): Instituto Andaluz del Patrimonio Histórico, 2019, pp. 178-195.

[81] E.M. Diz-Mellado, Estudio de estructura y cimentación de la Capilla del Sagrario de la Catedral de Sevilla, June 2016. https://idus.us.es/xmlui/handle/11441/45741. (Accessed 1 October 2016).

[82] Ministerio de Fomento, Documento Básico Seguridad Estructural vol. 2013, DB-SE, 2007. 